DOE/ID-22236

Prepared in cooperation with the U.S. Department of Energy

\title{
Hydrologic Influences on Water-Level Changes in the Eastern Snake River Plain Aquifer at and near the Idaho National Laboratory, Idaho, 1949-2014
}

Scientific Investigations Report 2015-5085 
Cover: Hydrologic technician Jayson Blom, U.S. Geological Survey (USGS) taking water-level measurement at well CWP-5. (Photograph by Roy Bartholomay, USGS Idaho National Laboratory Project Office, Idaho, April 13, 2015.) 


\section{Hydrologic Influences on Water-Level Changes in the Eastern Snake River Plain Aquifer at and near the Idaho National Laboratory, Idaho, 1949-2014}

By Roy C. Bartholomay and Brian V. Twining

DOE/ID-22236

Prepared in cooperation with the U.S. Department of Energy

Scientific Investigations Report 2015-5085 


\title{
U.S. Department of the Interior SALLY JEWELL, Secretary
}

\section{U.S. Geological Survey \\ Suzette M. Kimball, Acting Director}

\author{
U.S. Geological Survey, Reston, Virginia: 2015
}

For more information on the USGS - the Federal source for science about the Earth, its natural and living resources, natural hazards, and the environment—visit http://www.usgs.gov or call 1-888-ASK-USGS.

For an overview of USGS information products, including maps, imagery, and publications, visit http://www.usgs.gov/pubprod/.

Any use of trade, firm, or product names is for descriptive purposes only and does not imply endorsement by the U.S. Government.

Although this information product, for the most part, is in the public domain, it also may contain copyrighted materials as noted in the text. Permission to reproduce copyrighted items must be secured from the copyright owner.

Suggested citation:

Bartholomay, R.C., and Twining, B.V., 2015, Hydrologic influences on water-level changes in the eastern Snake River Plain aquifer at and near the Idaho National Laboratory, Idaho, 1949-2014: U.S. Geological Survey Scientific Investigations Report 2015-5085 (DOE/ID-22236), 36 p., http://dx.doi.org/10.3133/sir20155085.

ISSN 2328-0328 (online) 


\section{Contents}

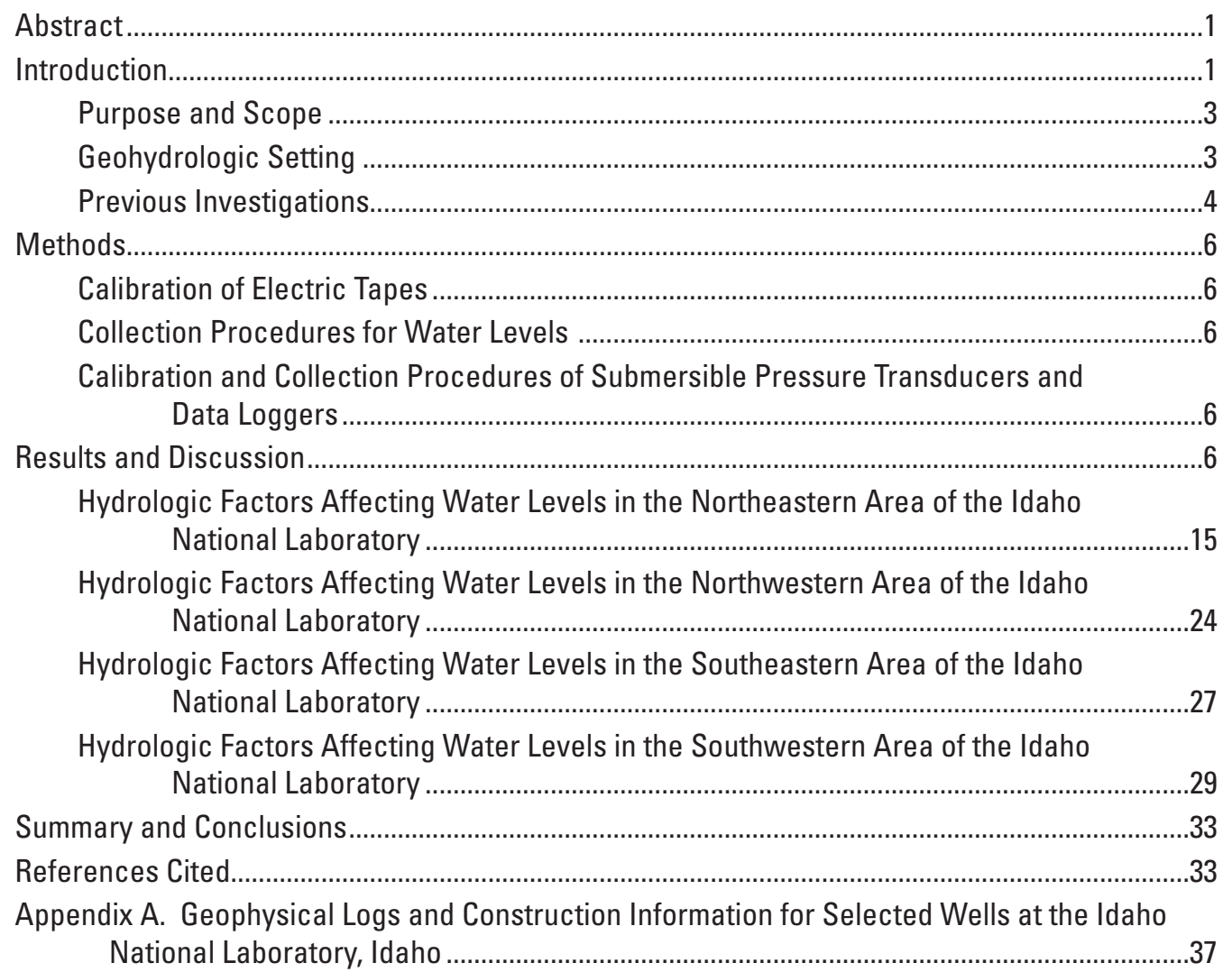




\section{Figures}

1. Map showing location of selected facilities and inset areas for selected facilities, Idaho National Laboratory, Idaho ..........................................................................

2. Map showing location of wells used for water-level measurements at and near the Idaho National Laboratory, Idaho

3. Map showing location of wells used for water-level measurements near the Advanced Test Reactor Complex, the Idaho Nuclear Technology and Engineering Center, the Naval Reactors Facility, and the Radioactive Waste Management Complex, Idaho National Laboratory, Idaho.

4. Map showing water level above current pumps in wells at and near the Idaho National Laboratory, Idaho.

5. Map showing water level above current pumps in wells near the Advanced Test Reactor Complex, the Idaho Nuclear Technology and Engineering Center, the Naval Reactors Facility, and the Radioactive Waste Management Complex, Idaho National Laboratory, Idaho

6. Graphs showing water levels in wells USGS 21, USGS 26, USGS 27, and USGS 32 in the northeastern area of the Idaho National Laboratory, Idaho, 1952-2014

7. Graphs showing water levels in wells USGS 1 , USGS 19, USGS 20, USGS 21 , and USGS 27, Idaho National Laboratory, Idaho, 2012-2014.

8. Geophysical logs for wells USGS 27 and ANP-6 at the Idaho National Laboratory, Idaho

9. Graphs showing water levels in wells Site 14, USGS 12, USGS 19, and USGS 25 in the northwestern part of the Idaho National Laboratory, Idaho, 1950-2014

10. Graphs showing streamflow at U.S. Geological Survey streamgaging stations along the Big Lost River: Big Lost River below Mackay Reservoir, near Mackay, Idaho, water years 1905, 1913-14, and 1920-2014; Big Lost River below the Idaho National Laboratory (INL) diversion, near Arco; and INL diversion at head, near Arco, Idaho, water years 1965-2014.

11. Graphs showing water levels in wells Highway 2, USGS 1, USGS 2, and USGS 5 in the southeastern area of the Idaho National Laboratory, Idaho, 1949-2014.

12. Graphs showing water levels in wells MTR Test, USGS 8, USGS 9, USGS 20, USGS 97, and USGS 104 in the southwestern area of the Idaho National Laboratory, Idaho, 1949-2014.

\section{Tables}

1. Summary of selected previous hydrologic investigations with water level information for groundwater, Idaho National Laboratory, Idaho, 1949-2011

2. Monitoring well site information and water level information at and near the Idaho National Laboratory, Idaho

3. Production or public supply well site information at and near the Idaho National Laboratory, Idaho.....

4. Water level information and transmissivity information for wells with less than 20 feet of water above pump at the Idaho National Laboratory, Idaho. 


\section{Conversion Factors}

Inch/Pound to International System of Units

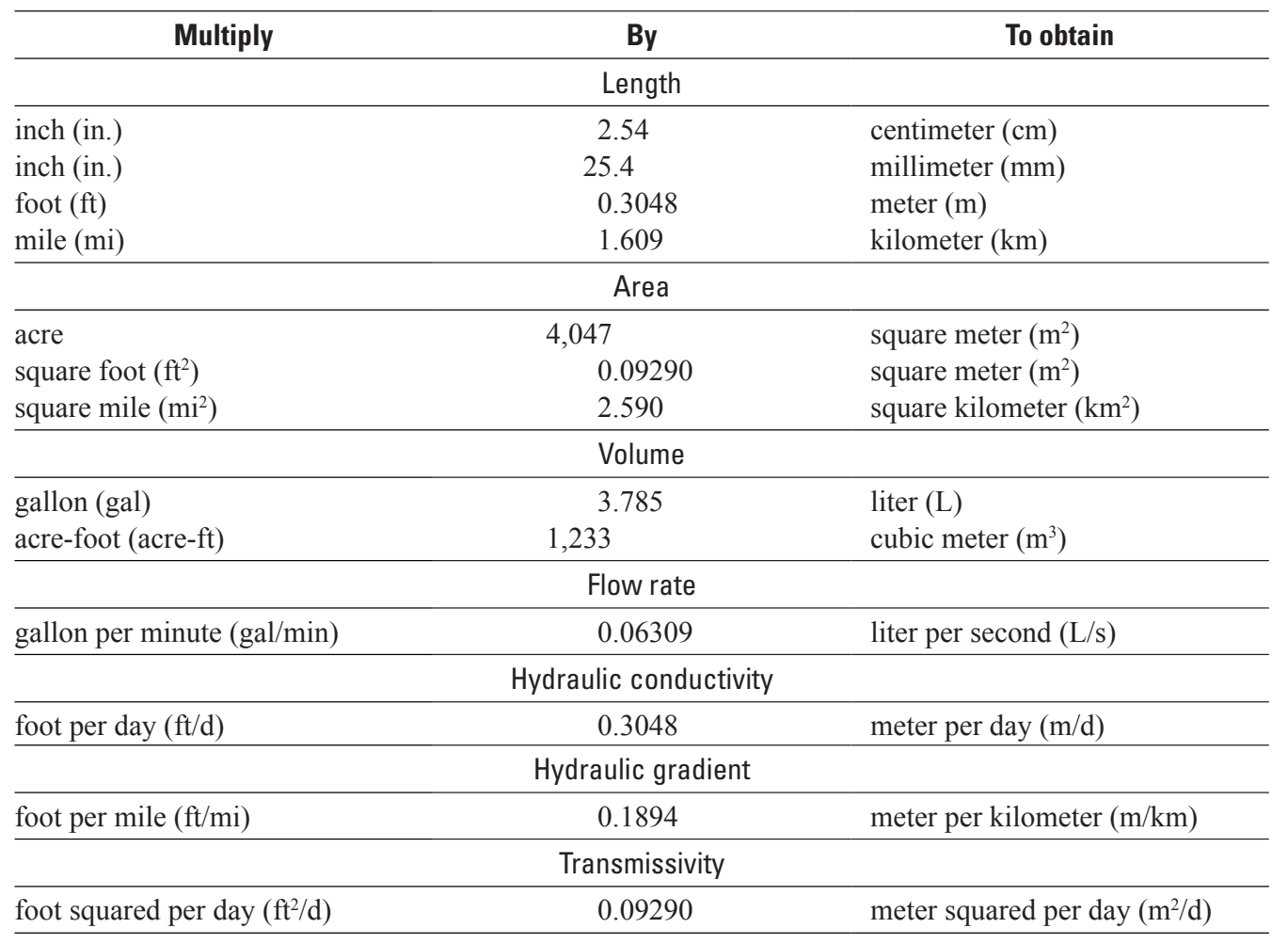

Temperature in degrees Celsius $\left({ }^{\circ} \mathrm{C}\right)$ may be converted to degrees Fahrenheit $\left({ }^{\circ} \mathrm{F}\right)$ as ${ }^{\circ} \mathrm{F}=\left(1.8 \times{ }^{\circ} \mathrm{C}\right)+32$.

Temperature in degrees Fahrenheit $\left({ }^{\circ} \mathrm{F}\right)$ may be converted to degrees Celsius $\left({ }^{\circ} \mathrm{C}\right)$ as ${ }^{\circ} \mathrm{C}=\left({ }^{\circ} \mathrm{F}-32\right) / 1.8$.

\section{Datums}

Vertical coordinate information is referenced to the North American Vertical Datum of 1929 (NAVD 29).

Horizontal coordinate information is referenced to the North American Datum of 1927 (NAD 27). Altitude, as used in this report, refers to distance above the vertical datum. 



\title{
Hydrologic Influences on Water-Level Changes in the Eastern Snake River Plain Aquifer at and near the Idaho National Laboratory, Idaho, 1949-2014
}

\author{
By Roy C. Bartholomay and Brian V. Twining
}

\section{Abstract}

The U.S. Geological Survey, in cooperation with the U.S. Department of Energy, has maintained a water-level monitoring program at the Idaho National Laboratory (INL) since 1949 to systematically measure water levels to provide long-term information on groundwater recharge, discharge, movement, and storage in the eastern Snake River Plain (ESRP) aquifer. During 2014, water levels in the ESRP aquifer reached all-time lows for the period of record, prompting this study to assess the effect that future water-level declines may have on pumps and wells. Water-level data were compared with pump-setting depth to determine the hydraulic head above the current pump setting. Additionally, geophysical logs were examined to address changes in well productivity with water-level declines. Furthermore, hydrologic factors that affect water levels in different areas of the INL were evaluated to help understand why water-level changes occur.

Review of pump intake placement and 2014 water-level data indicates that 40 wells completed within the ESRP aquifer at the INL have 20 feet (ft) or less of head above the pump. Nine of the these wells are located in the northeastern and northwestern areas of the INL where recharge is predominantly affected by irrigation, wet and dry cycles of precipitation, and flow in the Big Lost River. Water levels in northeastern and northwestern wells generally show water-level fluctuations of as much as $4.5 \mathrm{ft}$ seasonally and show declines as much as $25 \mathrm{ft}$ during the past 14 years.

In the southeastern area of the INL, seven wells were identified as having less than $20 \mathrm{ft}$ of water remaining above the pump. Most of the wells in the southeast show less decline over the period of record compared with wells in the northeast; the smaller declines are probably attributable to less groundwater withdrawal from pumping of wells for irrigation. In addition, most of the southeastern wells show only about a 1-2 ft fluctuation seasonally because they are less influenced by groundwater withdrawals for irrigation.

In the southwestern area of the INL, 24 wells were identified as having less than $20 \mathrm{ft}$ of water remaining above the pump. Wells in the southwest also only show small 1-2 ft fluctuations seasonally because of a lack of irrigation influence. Wells show larger fluctuation in water levels closer to the Big Lost River and fluctuate in response to wet and dry cycles of recharge to the Big Lost River.

Geophysical logs indicate that most of the wells evaluated will maintain their current production until the water level declines to the depth of the pump. A few of the wells may become less productive once the water level gets to within about $5 \mathrm{ft}$ from the top of the pump. Wells most susceptible to future drought cycles are those in the northeastern and northwestern areas of the INL.

\section{Introduction}

The Idaho National Laboratory (INL), operated by the U.S. Department of Energy (DOE), encompasses about $890 \mathrm{mi}^{2}$ of the eastern Snake River Plain (ESRP) in southeastern Idaho (fig. 1). The INL was established in 1949 to develop atomic energy, nuclear safety, defense programs, environmental research, and advanced energy concepts. Wastewater disposal sites at the Test Area North (TAN), the Naval Reactors Facility (NRF), the Advanced Test Reactor Complex (ATR Complex), and the Idaho Nuclear Technology and Engineering Center (INTEC) (fig. 1) have contributed radioactive- and chemical-waste contaminants to the ESRP aquifer. These sites incorporated various wastewater disposal methods, including lined evaporation ponds, unlined percolation (infiltration) ponds and ditches, drain fields, and injection wells. Waste materials buried in shallow pits and trenches within the Subsurface Disposal Area (SDA) at the Radioactive Waste Management Complex (RWMC) also have contributed contaminants to groundwater.

Since 1949, the U.S. Geological Survey (USGS) has worked in cooperation with the DOE at the INL to define: (1) the quality and availability of water for human consumption, (2) the usability of the water for supporting construction and cooling of facilities, and for diluting concentrated waste streams, (3) the location and movement of contaminants in the ESRP aquifer and perched groundwater zones, (4) the sources of recharge to the aquifer, (5) an early detection network for contaminants moving past the INL 


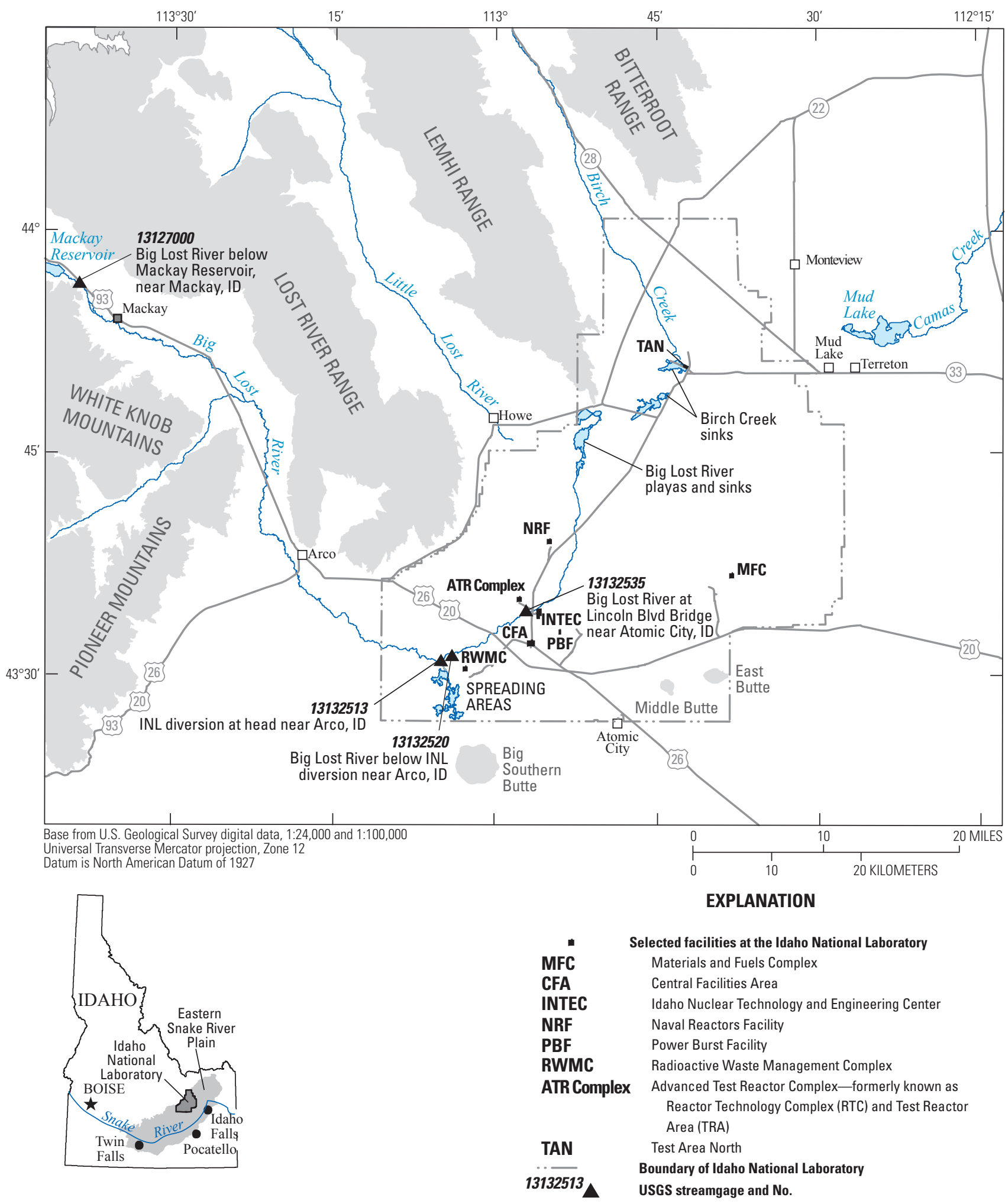

Figure 1. Location of selected facilities and inset areas for selected facilities, Idaho National Laboratory, Idaho. 
boundaries, and (6) the processes controlling the origin and distribution of contaminants and naturally occurring constituents in the aquifer (Ackerman and others, 2010).

The USGS has maintained a water-level monitoring program at the INL since 1949 to systematically measure water-levels to provide long-term information on the ESRP aquifer that may affect groundwater recharge, discharge, movement, and storage. Collection of water-level data is obtained manually by use of electronic (e)-tapes and continuous data loggers. Water-levels are collected continuously, monthly, quarterly, semi-annually, or annually depending on historical data, research needs, and changes in each wells hydrograph (Bartholomay and others, 2014, appendix B).

\section{Purpose and Scope}

The purpose of this report is to evaluate water-level data for wells constructed at the INL and to assess how continued water-level declines will affect well productivity. Water levels are compared with pump depth to determine the hydraulic head above the pumps. Geophysical logs are presented for selected wells to describe expected productivity based on aquifer properties as water levels decline towards the depth of the pump. Hydrologic factors affecting water levels in different areas of the INL are discussed to provide an understanding of why water-level declines and fluctuations occur.

\section{Geohydrologic Setting}

The INL is located on the west-central part of the ESRP. The ESRP is a northeast-trending structural downwarp about $200 \mathrm{mi}$ long and 50-70 mi wide (fig. 1). The basin has been filled with basaltic lava flows interbedded with terrestrial sediments. The basaltic rocks and sedimentary deposits combine to form the ESRP aquifer, which is the primary source of groundwater for the ESRP.

The ESRP aquifer is one of the most productive aquifers in the United States (U.S. Geological Survey, 1985, p. 193). Groundwater generally moves from northeast to southwest, and eventually discharges to springs along the Snake River downstream of Twin Falls, Idaho, about 100 mi southwest of the INL (fig. 1). Groundwater moves horizontally through basalt interflow zones and vertically through joints and interfingering edges of basalt flows. Infiltration of surface water, heavy pumpage, geohydrologic conditions, and seasonal fluxes of recharge and discharge locally affect the movement of groundwater (Garabedian, 1986). The ESRP aquifer is recharged primarily from infiltration of applied irrigation water, infiltration of streamflow, groundwater inflow from adjoining mountain drainage basins, and infiltration of precipitation (Ackerman and others, 2006).

At the INL, depth to water in wells completed in the ESRP aquifer ranges from about $200 \mathrm{ft}$ below land surface
(BLS) in the northern part of the INL to more than $900 \mathrm{ft}$ BLS in the southeastern part of the INL. A significant proportion of the groundwater moves through the upper 200-800 $\mathrm{ft}$ of basaltic rock (Mann, 1986, p. 21). Ackerman (1991, p. 30) and Bartholomay and others (1997, table 3 ) reported transmissivity values for basalt in the upper part of the aquifer ranging from 1.1 to $760,000 \mathrm{ft}^{2} / \mathrm{d}$. The hydraulic gradient at the INL ranges from 2 to $10 \mathrm{ft} / \mathrm{mi}$, with an average of $4 \mathrm{ft} / \mathrm{mi}$ (Davis and others, 2013, fig. 9). Horizontal flow velocities of 2-26 ft/d have been calculated based on the movement of various constituents in different areas of the aquifer at and near the INL (Robertson and others, 1974; Mann and Beasley, 1994; Cecil and others, 2000; Plummer and others, 2000; and Busenberg and others, 2001). These flow rates equate to a travel time of about 50-700 years for water beneath the INL to travel to springs that discharge at the terminus of the ESRP groundwater-flow system near Twin Falls, Idaho. Localized tracer tests at the INL have shown that vertical- and horizontal-transport rates are as high as 60-150 ft/d (Nimmo and others, 2002; Duke and others, 2007).

Olmsted (1962), Robertson and others (1974), and Busenberg and others (2001) classified groundwater at the INL based on chemical types derived from dissolution of the rocks and minerals within the recharge source areas. Olmsted's type A water included calcium and magnesium concentrations that constituted at least 85 percent of the cations and bicarbonate that constituted at least 70 percent of the anions. Type A water is present in the northwestern and southwestern part of the INL. Type A water is attributed to seepage loss from the Big Lost River and from groundwater underflow from the Big Lost River, Little Lost River, and Birch Creek drainage basins to the west and northwest of the INL (fig. 1) that contain alluvium derived from Paleozoic carbonate rocks from the surrounding mountains.

Olmsted's type B water, which is characterized by higher equivalent fractions of sodium, potassium, fluoride, and silica than type A water, underlies much of the northeastern and southeastern part of the INL and is often referred to as regional water. The groundwater originates from the area northeast of the INL that consists of a much higher fraction of rhyolitic and andesitic volcanic rocks than mountains west and northwest of the INL that contribute to Type A water. Busenberg and others (2001) used age dating techniques of chlorofluorocarbons (CFCs), sulfur hexafluoride, and tritium/helium to further classify the regional water at the INL into two types based on the recharge type of the young fraction of groundwater. Water in the southeastern part of the INL represented a binary mixture of old (water greater than 40 and 55 years old that did not contain tritium or CFCs, respectively) regional groundwater underflow with young water derived from rapid, focused recharge, probably from precipitation infiltration. Water in the northeastern part of the INL is old, regional groundwater underflow that is mixed with local rapid, focused recharge; slow, diffuse areal recharge through the unsaturated zone; and agricultural return flow from the Mud Lake and Terreton areas (figs. 1 and 2). 


\section{Previous Investigations}

Numerous previous investigations on the hydrology and geology at the INL have been done by INL contractors, state agencies, and the USGS. The USGS provides a list of references and hyperlinks to published reports from its previous INL studies at the USGS Idaho National Laboratory Project Office web site at: http://id.water.usgs.gov/INL/Pubs/ index.html.

Water-level data for wells in the USGS INL Project Office water level monitoring program were published in past USGS reports. Barraclough and others (1984) published data from selected wells from 1949 through 1982, and Ott and others (1992) published data from selected wells from 1983 through 1990. Starting in the mid-1990s, USGS water-level data became more easily accessible, and tables of water-level data and presentation quality hydrographs for wells can now be accessed through USGS websites. Water-level information from wells at the INL are available at: http://maps.waterdata. usgs.gov/mapper/index.html? SiteGroups $=$ gw, act\&MapCent erX $=-112.84 \&$ MapCenterY=43.58\&MapZoom $=10$.

Water level changes at and near the INL are evaluated every 3-4 years; results of the water table altitude and changes in groundwater levels are summarized in the INL hydrologic conditions reports. Table 1 summarizes previous hydrologic condition investigations at and near the INL, specifies the periods covered by those investigations, and lists report citations. Full references for these citations are available in section, "References Cited."

Table 1. Summary of selected previous hydrologic investigations with water level information for groundwater, Idaho National Laboratory, Idaho, 1949-2011.

[Abbreviations: ATR Complex, Advanced Test Reactor Complex (formerly the TRA, Test Reactor Area and the RTC, Reactor Technology Complex); NRTS, National Reactor Testing Station; RWMC, Radioactive Waste Management Complex; INEL, Idaho National Engineering Laboratory; INEEL, Idaho National Engineering and Environmental Laboratory; INL, Idaho National Laboratory; INTEC, Idaho Nuclear Technology and Engineering Center (formerly the ICPP, Idaho Chemical Processing Plant); ESRP, eastern Snake River Plain]

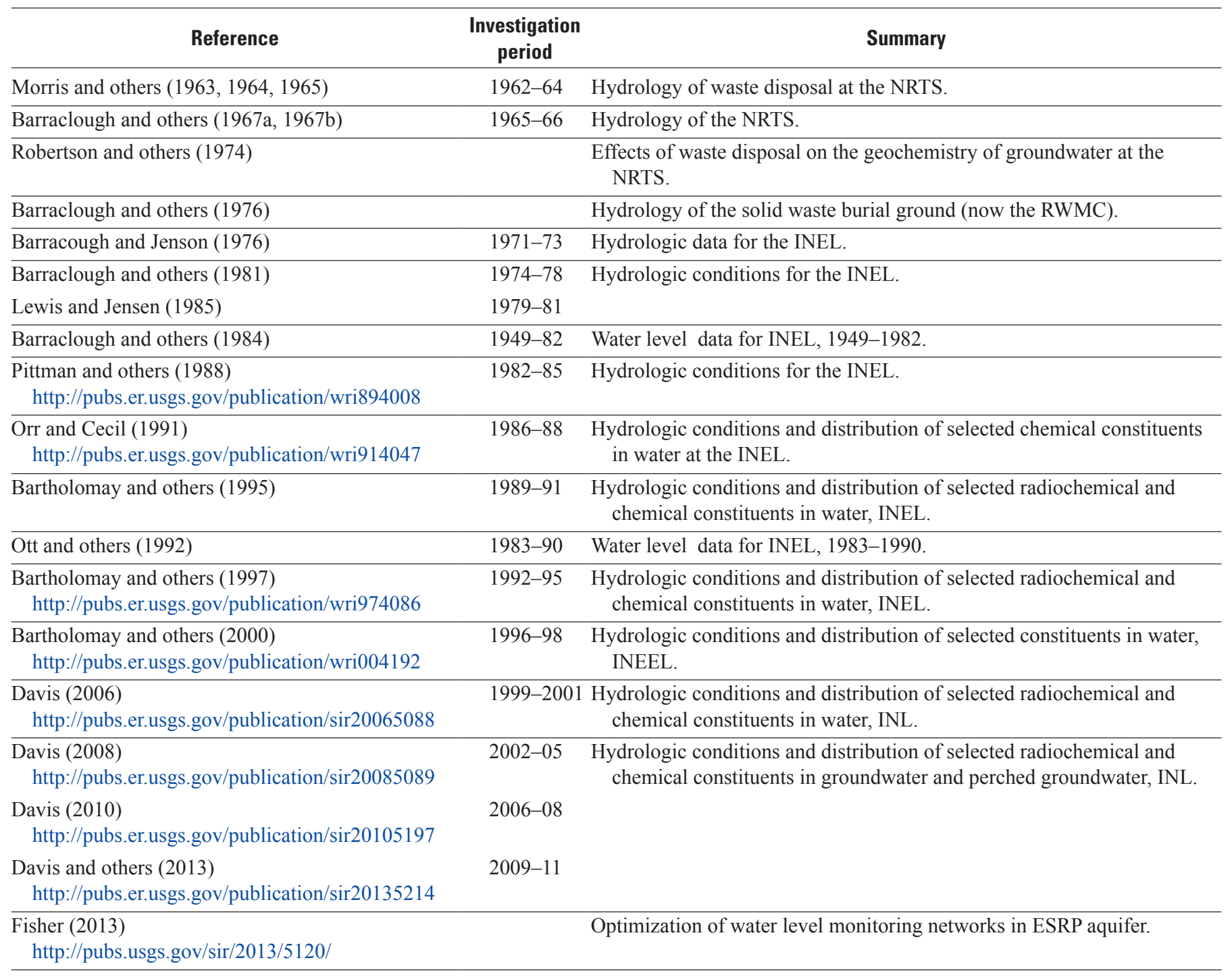




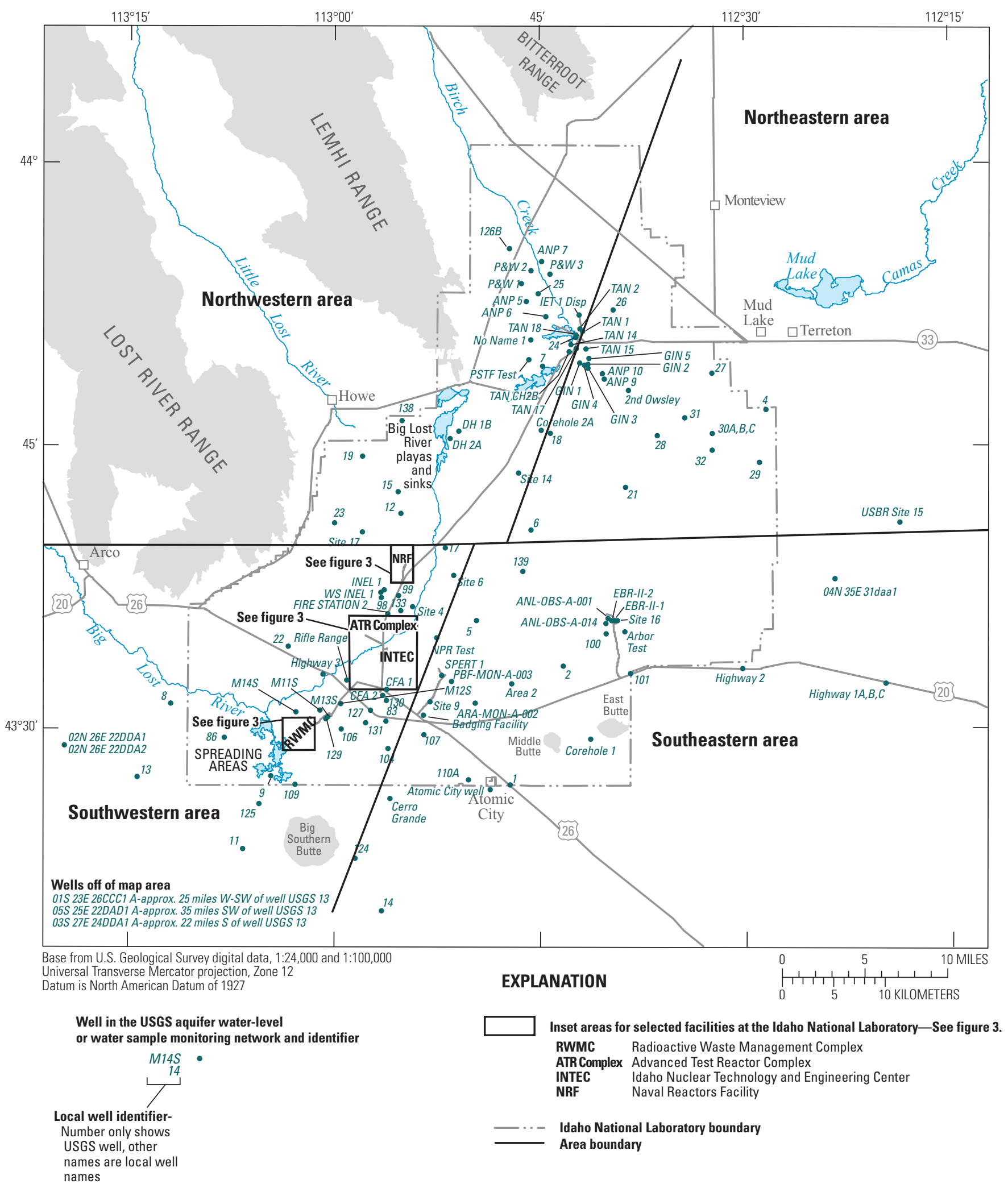

Figure 2. Location of wells used for water-level measurements at and near the Idaho National Laboratory, Idaho. 
An optimization of the INL water-level monitoring network using a kriging-based genetic algorithm method was completed in 2013 to determine which set of wells, if removed, would lead to the smallest error in determining the water-table elevation (Fisher, 2013). The network design tool was applied to 171 wells at the INL. The study showed that as many as 40 wells could be removed from the INL network before the water-table map degradation accelerated.

\section{Methods}

Calibration of water-level measurement equipment and use of appropriate field procedures are crucial in assuring reliable water-level data is collected from open boreholes and data loggers. All sites are surveyed with known measuring points, and the water-level is calculated from a known land surface datum.

\section{Calibration of Electric Tapes}

The USGS INL Project Office started the use of electric (e)-tapes in 2003; prior to 2003, stainless steel tapes were used. E-tapes are calibrated against a reference steel tape, maintained in the office for calibration use only, and a calibration table is generated for each e-tape in 50-ft increments to maintain measurement consistency. Each e-tape is initially calibrated before use in the field and recalibrated annually or more frequently if the tape is used often or subjected to abnormal stress that may have caused it to stretch. Procedures used for calibration are given in Bartholomay and others (2014).

\section{Collection Procedures for Water Levels}

All water-level measurements taken with an e-tape have a calibration and measuring point correction applied to them. Several wells also have deviation corrections applied; these corrections have been calculated from geophysical deviation $\log$ files. All data are entered in the Multi Optional Network Key Entry System for electronic download and on a field sheet for back up. Collection procedures are given in Bartholomay and others (2014).

\section{Calibration and Collection Procedures of Submersible Pressure Transducers and Data Loggers}

The USGS INL Project office maintains six vented pressure transducers in observation wells for long-term continuous monitoring of water levels. These wells are scheduled for either semi-annual or quarterly visits to download the data and calibrate the transducers. The procedure for retrieving water-level measurements from pressure transducers and for maintaining the pressure transducers is given in Bartholomay and others (2014).

\section{Results and Discussion}

As of 2014, water levels from the ESRP aquifer are collected either continuously, monthly, quarterly, semi-annually, or annually at 177 wells (Bartholomay and others, 2014, appendix B) at and near the INL (figs. 2 and 3) depending on historical data, research needs, and changes in the hydrograph. Water-level data collected during 2014, submersible pump settings (if applicable), and reported well depths are given in table 2; similar information is provided for production and public supply wells in table 3. Most of the production and public supply wells do not have water-level measurement lines, so an approximate current water level from a nearby well is given to provide general information as to how much water is still above the pumps. As indicated in table 3 , none of the production or public supply wells at the INL have water levels less than $20 \mathrm{ft}$ above their pumps, so there is no concern of these wells pumping dry in the near future.

Figures 4 and 5 show which wells currently have less than $10 \mathrm{ft}$ of water above their pump and which wells have less than $20 \mathrm{ft}$ of water above their pumps. The depth of $10 \mathrm{ft}$ was chosen because the last drought period from 2000 to 2005 showed about a $10-\mathrm{ft}$ decline in much of the aquifer at the INL. The depth of $20 \mathrm{ft}$ was chosen because wells in the northern part of the INL have declined by more than $20 \mathrm{ft}$ in the past 14 years. Most of the discussion in the following sections will focus on these wells.

For discussion in this report, the INL was divided into quarters based on general hydrologic factors and water type (fig. 2). The northeastern and southeastern areas generally consist of wells composed of mostly regional recharge as defined by Busenberg and others (2001) and by Fisher and others (2012). The northwestern and southwestern areas are defined as being mostly recharged by western stream tributary and underflow recharge from the Big Lost River, Little Lost River, and Birch Creek. The boundary separating northern areas from southern areas was an arbitrary line drawn north of the NRF area (fig. 2). Wells with at least quarterly measurements that were spatially distributed were used to represent water level changes in the different areas of the aquifer. 


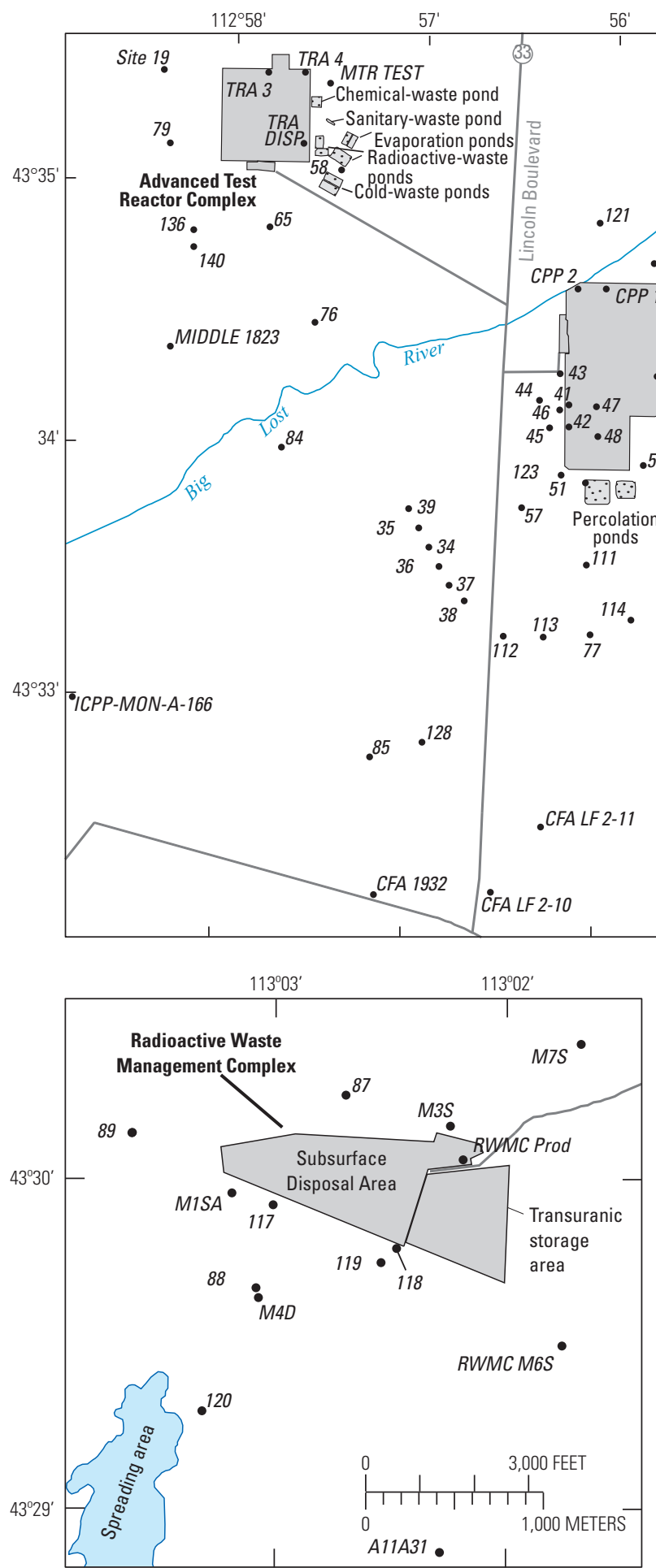

Base from U.S. Geological Survey digital data, 1:24,000 and 1:100,000 Universal Transverse Mercator projection, Zone 12

Datum is North American Datum of 1927

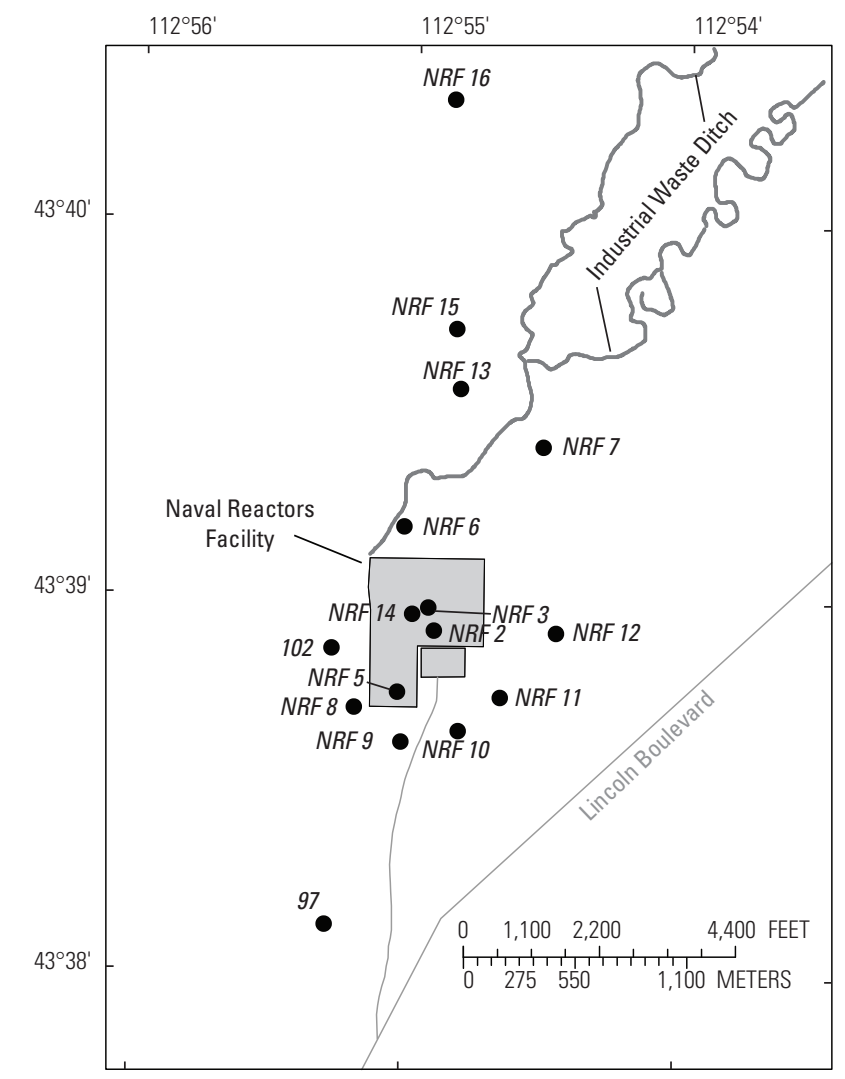

Figure 3. Location of wells used for water-level measurements near the Advanced Test Reactor Complex, the Idaho Nuclear Technology and Engineering Center, the Naval Reactors Facility, and the Radioactive Waste Management Complex, Idaho National Laboratory, Idaho. 
Table 2. Monitoring well site information and water level information at and near the Idaho National Laboratory, Idaho.

[Location of wells is shown in figures 2 and 3. Water level measurements are given in feet with reference to National Geodetic Vertical Datum of 1929. Local name is the local well identifier used in this study. Site identifier is the unique numerical identifier used to access well data from the USGS National Water Information System (http://waterdata.usgs.gov/nwis). Pump depth is the last known depth of pump installed in the well. Abbreviations: ft, feet; BLS, below land surface; NA, not applicable; unk, not available; *, well has been measured as dry since 2013]

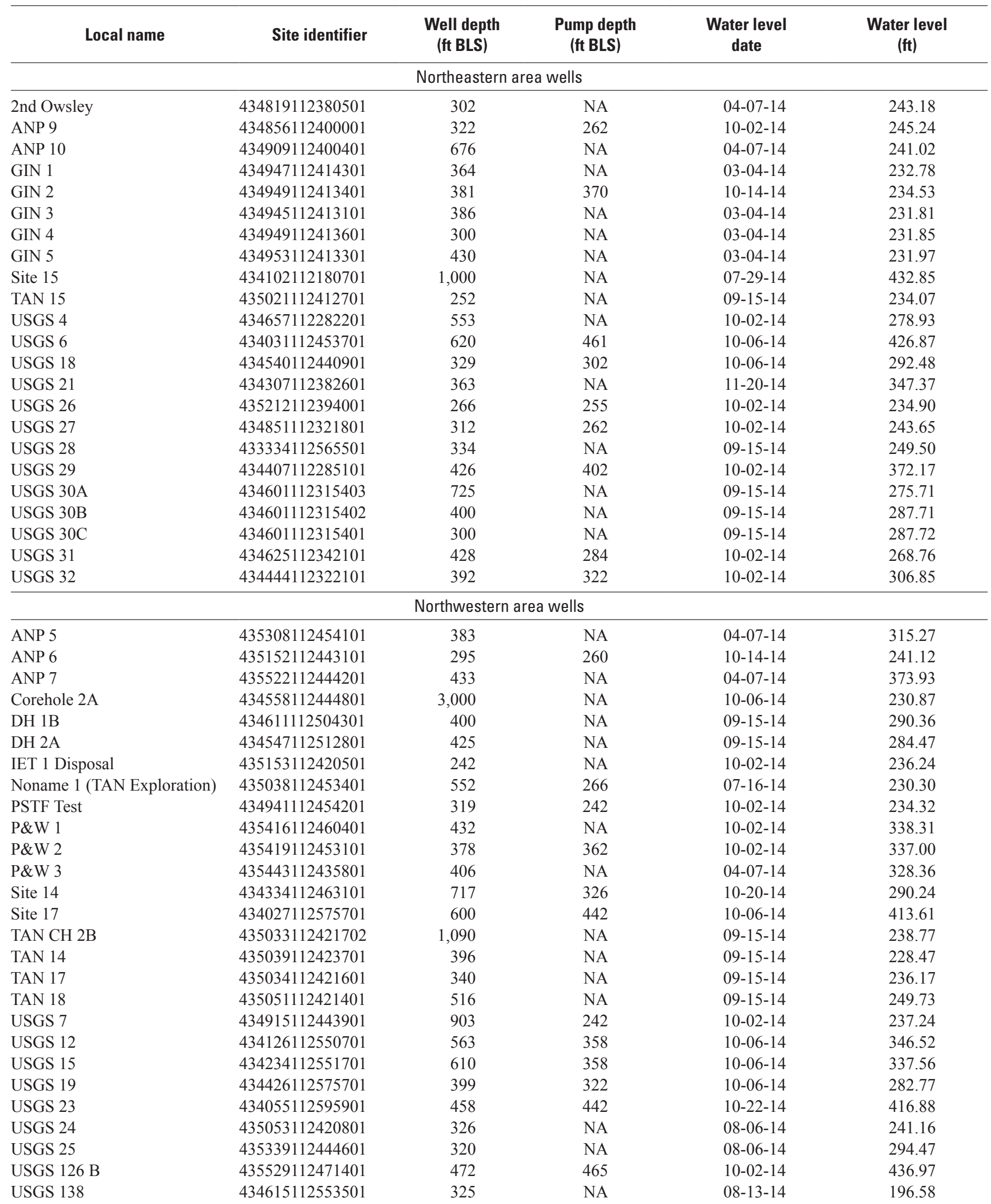


Table 2. Monitoring well site information and water level information at and near the Idaho National Laboratory, Idaho. - Continued

[Location of wells is shown in figures 2 and 3. Water level measurements are given in feet with reference to National Geodetic Vertical Datum of 1929. Local name is the local well identifier used in this study. Site identifier is the unique numerical identifier used to access well data from the USGS National Water Information System (http://waterdata.usgs.gov/nwis). Pump depth is the last known depth of pump installed in the well. Abbreviations: ft, feet; BLS, below land surface; NA, not applicable; unk, not available; *, well has been measured as dry since 2013]

\begin{tabular}{|c|c|c|c|c|c|}
\hline Local name & Site identifier & $\begin{array}{l}\text { Well depth } \\
\text { (ft BLS) }\end{array}$ & $\begin{array}{l}\text { Pump depth } \\
\text { (ft BLS) }\end{array}$ & $\begin{array}{c}\text { Water level } \\
\text { date }\end{array}$ & $\begin{array}{c}\text { Water level } \\
\text { (ft) }\end{array}$ \\
\hline \multicolumn{6}{|c|}{ Southeastern area wells } \\
\hline ANL OBS A 001 & 433545112394101 & 1,910 & unk & $03-10-14$ & 646.54 \\
\hline ANL OBS-A 014 & 433537112393801 & 682 & unk & $03-10-14$ & 645.34 \\
\hline ARA-MON-A-002 & 433054112492102 & 620 & 604 & $10-09-14$ & 600.32 \\
\hline Cerro Grande & 432618112555501 & 562 & NA & $12-03-13 *$ & 560.68 \\
\hline Corehole 1 & 432927112410101 & 2,000 & NA & $10-01-14$ & 943.12 \\
\hline Highway 1A & 433218112191603 & 1,147 & NA & 09-08-14 & 596.15 \\
\hline Highway 1B & 433218112191602 & 982 & NA & $09-08-14$ & 594.91 \\
\hline Highway 1C & 433218112191601 & 800 & NA & $09-08-14$ & 594.05 \\
\hline USGS 2 & 433320112432301 & 699 & 685 & $10-01-14$ & 670.16 \\
\hline USGS 5 & 433543112493801 & 494 & 488 & $10-07-14$ & 480.41 \\
\hline USGS 14 & 432019112563201 & 752 & 739 & $10-14-14$ & 720.95 \\
\hline USGS 100 & 433503112400701 & 750 & 696 & $10-01-14$ & 688.15 \\
\hline USGS 101 & 433255112381801 & 842 & 800 & 09-08-14 & 781.53 \\
\hline USGS 107 & 432942112532801 & 690 & 509 & $10-08-14$ & 487.88 \\
\hline USGS 110A & 432717112501502 & 644 & 612 & $10-01-14$ & 571.88 \\
\hline USGS 124 & 432307112583101 & 800 & 737 & $10-01-14$ & 688.23 \\
\hline USGS 139A & 433823112460402 & 774 & NA & $10-06-14$ & 478.63 \\
\hline USGS 139B & 433823112460401 & 610 & NA & $10-06-14$ & 480.81 \\
\hline 04N 35E 31 daa1 & 433759112225401 & unk & NA & 04-03-14 & 618.86 \\
\hline \multicolumn{6}{|c|}{ Southwestern area wells } \\
\hline USGS 22 & 433422113031701 & 657 & 643 & $10-01-14$ & 618.80 \\
\hline USGS 34 & 433334112565501 & 700 & 518 & $04-07-14$ & 482.75 \\
\hline USGS 35 & 433339112565801 & 579 & 523 & $10-08-14$ & 484.71 \\
\hline USGS 36 & 433330112565201 & 567 & 521 & $10-08-14$ & 484.30 \\
\hline USGS 37 & 433326112564801 & 572 & 506 & $10-08-14$ & 483.99 \\
\hline USGS 38 & 433322112564301 & 724 & 522 & $04-07-14$ & 483.20 \\
\hline USGS 39 & 433343112570001 & 492 & 487 & $07-17-14$ & 485.66 \\
\hline USGS 41 & 433409112561301 & 666 & 502 & $10-09-14$ & 471.07 \\
\hline USGS 42 & 434004112561301 & 678 & 502 & $04-10-14$ & 470.39 \\
\hline USGS 43 & 433415112561501 & 564 & 522 & $10-06-14$ & 470.41 \\
\hline USGS 44 & 433409112562101 & 650 & 499 & $04-09-14$ & 470.88 \\
\hline USGS 45 & 433402112561801 & 651 & 502 & $10-06-14$ & 473.37 \\
\hline USGS 46 & 433407112561501 & 651 & 502 & $04-09-14$ & 469.72 \\
\hline USGS 47 & 433407112560301 & 651 & 486 & $10-12-10$ & 469.00 \\
\hline USGS 48 & 433401112560301 & 750 & 503 & $10-09-14$ & 471.55 \\
\hline USGS 51 & 433350112560601 & 647 & 501 & $04-09-14$ & 470.11 \\
\hline USGS 52 & 433414112554201 & 602 & 500 & $10-08-14$ & 464.17 \\
\hline
\end{tabular}


Table 2. Monitoring well site information and water level information at and near the Idaho National Laboratory, Idaho.-Continued

[Location of wells is shown in figures 2 and 3. Water level measurements are given in feet with reference to National Geodetic Vertical Datum of 1929. Local name is the local well identifier used in this study. Site identifier is the unique numerical identifier used to access well data from the USGS National Water Information System (http://waterdata.usgs.gov/nwis). Pump depth is the last known depth of pump installed in the well. Abbreviations: ft, feet; BLS, below land surface; NA, not applicable; unk, not available; *, well has been measured as dry since 2013]

\begin{tabular}{|c|c|c|c|c|c|}
\hline Local name & Site identifier & $\begin{array}{l}\text { Well depth } \\
\text { (ft BLS) }\end{array}$ & $\begin{array}{l}\text { Pump depth } \\
\text { (ft BLS) }\end{array}$ & $\begin{array}{c}\text { Water level } \\
\text { date }\end{array}$ & $\begin{array}{c}\text { Water level } \\
\text { (ft) }\end{array}$ \\
\hline \multicolumn{6}{|c|}{ Southwestern area wells-Continued } \\
\hline USGS 57 & 433344112562601 & 582 & 514 & $10-06-14$ & 477.84 \\
\hline USGS 58 & 433500112572502 & 503 & 483 & $10-08-14$ & 472.70 \\
\hline USGS 59 & 433354112554701 & 587 & 480 & $10-08-14$ & 467.74 \\
\hline USGS 76 & 433425112573201 & 718 & 502 & $10-08-14$ & 484.91 \\
\hline USGS 77 & 433315112560301 & 586 & 502 & $10-07-14$ & 477.12 \\
\hline USGS 79 & 433505112581901 & 702 & 522 & $10-08-14$ & 485.40 \\
\hline USGS 82 & 433401112551001 & 693 & 508 & $10-07-14$ & 461.51 \\
\hline USGS 83 & 433023112561501 & 752 & 606 & $10-08-14$ & 506.97 \\
\hline USGS 84 & 433356112574201 & 505 & 498 & $10-22-14$ & 493.00 \\
\hline USGS 88 & 432940113030201 & 663 & 651 & $10-21-14$ & 599.72 \\
\hline USGS 89 & 433005113032801 & 637 & 635 & $10-08-14$ & 608.60 \\
\hline USGS 97 & 433807112551501 & 510 & 420 & $10-06-14$ & 397.16 \\
\hline USGS 98 & 433657112563601 & 508 & 440 & $10-14-14$ & 425.79 \\
\hline USGS 99 & 433705112552101 & 440 & 422 & $10-02-14$ & 410.18 \\
\hline USGS 102 & 433853112551601 & 445 & 422 & $11-24-14$ & 389.09 \\
\hline USGS 104 & 432856112560801 & 700 & 588 & $10-21-14$ & 563.31 \\
\hline USGS 106 & 432959112593101 & 760 & 612 & $10-20-14$ & 594.85 \\
\hline USGS 109 & 432701113025601 & 800 & 660 & $10-08-14$ & 627.21 \\
\hline USGS 111 & 433331112560501 & 560 & 506 & 04-08-14 & 475.74 \\
\hline USGS 112 & 433314112563001 & 507 & 500 & $10-07-14$ & 483.14 \\
\hline USGS 121 & 433450112560301 & 475 & 473 & $10-07-14$ & 464.32 \\
\hline USGS 123 & 433352112561401 & 514 & 481 & $10-06-14$ & 475.03 \\
\hline USGS 125 & 432602113052801 & 774 & 700 & $10-14-14$ & 635.11 \\
\hline USGS 127 & 433058112572201 & 596 & 546 & $10-08-14$ & 516.84 \\
\hline USGS 128 & 433250112565601 & 615 & 528 & $10-08-14$ & 490.41 \\
\hline USGS 129 & 433036113002701 & 660 & NA & $10-08-14$ & 605.58 \\
\hline USGS 130 & 433130112562801 & 636 & 527 & $10-23-14$ & 486.09 \\
\hline USGS 131 & 433036112581601 & 797 & NA & $10-08-14$ & 548.12 \\
\hline USGS 136 & 433447112581501 & 551 & 525 & $10-09-14$ & 489.98 \\
\hline
\end{tabular}


Table 2. Monitoring well site information and water level information at and near the Idaho National Laboratory, Idaho.—Continued

[Location of wells is shown in figures 2 and 3. Water level measurements are given in feet with reference to National Geodetic Vertical Datum of 1929. Local name is the local well identifier used in this study. Site identifier is the unique numerical identifier used to access well data from the USGS National Water Information System (http://waterdata.usgs.gov/nwis). Pump depth is the last known depth of pump installed in the well. Abbreviations: ft, feet; BLS, below land surface; NA, not applicable; unk, not available; *, well has been measured as dry since 2013]

\begin{tabular}{|c|c|c|c|c|c|}
\hline Local name & Site identifier & $\begin{array}{l}\text { Well depth } \\
\text { (ft BLS) }\end{array}$ & $\begin{array}{l}\text { Pump depth } \\
\text { (ft BLS) }\end{array}$ & $\begin{array}{c}\text { Water level } \\
\text { date }\end{array}$ & $\begin{array}{c}\text { Water level } \\
\text { (ft) }\end{array}$ \\
\hline \multicolumn{6}{|c|}{ Southwestern area wells_-Continued } \\
\hline USGS 140 & 433441112581201 & 546 & 526 & $12-04-14$ & 491.24 \\
\hline $\mathrm{A} 11 \mathrm{~A} 31$ & 432853113021701 & 675 & NA & 03-04-14 & 646.64 \\
\hline CFA 1932 & 433214112570101 & 525 & NA & $10-08-14$ & 494.06 \\
\hline Firestation 2 & 433548112562301 & 510 & NA & $09-22-14$ & 441.69 \\
\hline ICPP-Mon-A-166 & 433300112583301 & 527 & NA & $10-08-14$ & 511.75 \\
\hline INEL 1 & 433717112563501 & 10,333 & NA & $03-10-14$ & 314.57 \\
\hline MTR TEST & 433520112572601 & 588 & 486 & $10-08-14$ & 470.96 \\
\hline NPR Test & 433449112523101 & 600 & 486 & $10-15-14$ & 476.04 \\
\hline NRF 7 & 433920112543601 & 415 & 407 & $11-18-14$ & 381.12 \\
\hline NRF 8 & 433843112550901 & 420 & 411 & $11-24-14$ & 391.07 \\
\hline NRF 9 & 433840112550201 & 422 & 409 & $12-04-14$ & 392.08 \\
\hline NRF 10 & 433841112545201 & 427 & 408 & $11-17-14$ & 391.88 \\
\hline NRF 11 & 433847112544201 & 417 & 409 & $11-20-14$ & 389.41 \\
\hline NRF 12 & 433855112543201 & 421 & 414 & $11-18-14$ & 389.19 \\
\hline NRF 13 & 433928112545401 & 425 & 405 & $11-25-14$ & 380.17 \\
\hline NRF 14 & 433856112545901 & 550 & 425 & $11-19-14$ & 388.58 \\
\hline NRF 15-A & 433942112545002 & 759 & NA & $10-06-14$ & 379.99 \\
\hline NRF $15-\mathrm{B}$ & 433942112545001 & 759 & NA & $10-06-14$ & 375.74 \\
\hline NRF 16 & 434018112545101 & 422 & 402 & $11-20-14$ & 362.28 \\
\hline RWMC M14S & 433052113025001 & 634 & 633 & $10-23-14$ & 610.54 \\
\hline Site 6 & 433826112510701 & 523 & NA & 03-06-14 & 372.38 \\
\hline Site 19 & 433522112582101 & 860 & 486 & $10-15-14$ & 479.83 \\
\hline TRA Disposal & 433506112572301 & 1,267 & 507 & $10-23-14$ & 476.76 \\
\hline WS for INEL-1 & 433716112563601 & 490 & 483 & $10-07-14$ & 411.66 \\
\hline 01S 23E 26CCC1 & 431810113413601 & 1,031 & NA & 04-08-14 & 979.08 \\
\hline 02N 26E 22DDA1 & 432854113201001 & 719 & NA & $04-08-14$ & 662.25 \\
\hline 02N 26E 22DDA2 & 432854113201002 & 1,053 & NA & $04-08-14$ & 988.90 \\
\hline 03S 27E 24DDA1 & 430836113143401 & 901 & NA & 04-08-14 & 877.49 \\
\hline 05S 25E 22DAD1 & 425812113271201 & 581 & NA & 04-08-14 & 520.88 \\
\hline
\end{tabular}




\section{Hydrologic Influences on Water-Level Changes, Eastern Snake River Aquifer, Idaho National Laboratory, Idaho, 1949-2014}

Table 3. Production or public supply well site information at and near the Idaho National Laboratory, Idaho.

[Location of wells is shown in figures 2 and 3. Water level measurements are given in feet with reference to National Geodetic Vertical Datum of 1929. Local name is the local well identifier used in this study. Site identifier is the unique numerical identifier used to access well data from the USGS National Water Information System (http://waterdata.usgs.gov/nwis). Abbreviations: ft, feet; BLS, below land surface; unk, not available]

\begin{tabular}{|c|c|c|c|c|c|c|c|}
\hline Local name & Site identifier & $\begin{array}{l}\text { Well depth } \\
\text { (ft BLS) }\end{array}$ & $\begin{array}{l}\text { Pump depth } \\
\text { (ft BLS) }\end{array}$ & $\begin{array}{c}\text { Approximate } \\
\text { water level } \\
\text { (ft) }\end{array}$ & $\begin{array}{l}\text { Difference } \\
\quad \text { (ft) }\end{array}$ & \multicolumn{2}{|c|}{$\begin{array}{l}\text { Well used for approximate } \\
\text { water level and date }\end{array}$} \\
\hline NRF 2 & 433854112545401 & 528 & 446 & 387 & 59 & NRF 2 & $05-12-14$ \\
\hline NRF 3 & 433858112545501 & 546 & unk & 388 & unk & NRF 3 & $05-12-14$ \\
\hline TAN 2 & 435100112420701 & 340 & 279 & 241 & 38 & USGS 24 & $08-06-14$ \\
\hline \multicolumn{8}{|c|}{ Southwestern area wells } \\
\hline BFW & 433042112535101 & 644 & unk & 482 & unk & Site 9 & $07-17-14$ \\
\hline CFA 1 & 433204112562001 & 639 & 576 & 489 & 87 & CFA LF 2-10 & $07-16-14$ \\
\hline CFA 2 & 433144112563501 & 681 & 576 & 487 & 89 & USGS 130 & $09-02-14$ \\
\hline Highway 3 & 433256113002501 & 750 & 567 & 511 & 56 & ICPP Mon 166 & $07-16-14$ \\
\hline RIFLE RANGE & 433243112591101 & 620 & 580 & 511 & 69 & ICPP Mon 166 & $07-16-14$ \\
\hline RWMC Production & 433002113021701 & 685 & unk & 595 & unk & RWMC M3S & $04-07-14$ \\
\hline Site 4 & 433617112542001 & 495 & unk & 410 & unk & USGS 99 & $05-14-14$ \\
\hline TRA 3 & 433522112573501 & 602 & 585 & 471 & 114 & MTR Test & $09-22-14$ \\
\hline TRA 4 & 433521112574201 & 965 & unk & 471 & unk & MTR Test & $09-22-14$ \\
\hline \multicolumn{8}{|c|}{ Southeastern area wells } \\
\hline Atomic City & 432638112484101 & 639 & unk & 595 & unk & USGS 1 & $05-07-14$ \\
\hline EBR-II-1 & 433546112391601 & 745 & 719 & 646 & 73 & Site 16 & $03-10-14$ \\
\hline EBR-II-2 & 433544112391301 & 753 & 719 & 646 & 73 & Site 16 & $03-10-14$ \\
\hline
\end{tabular}




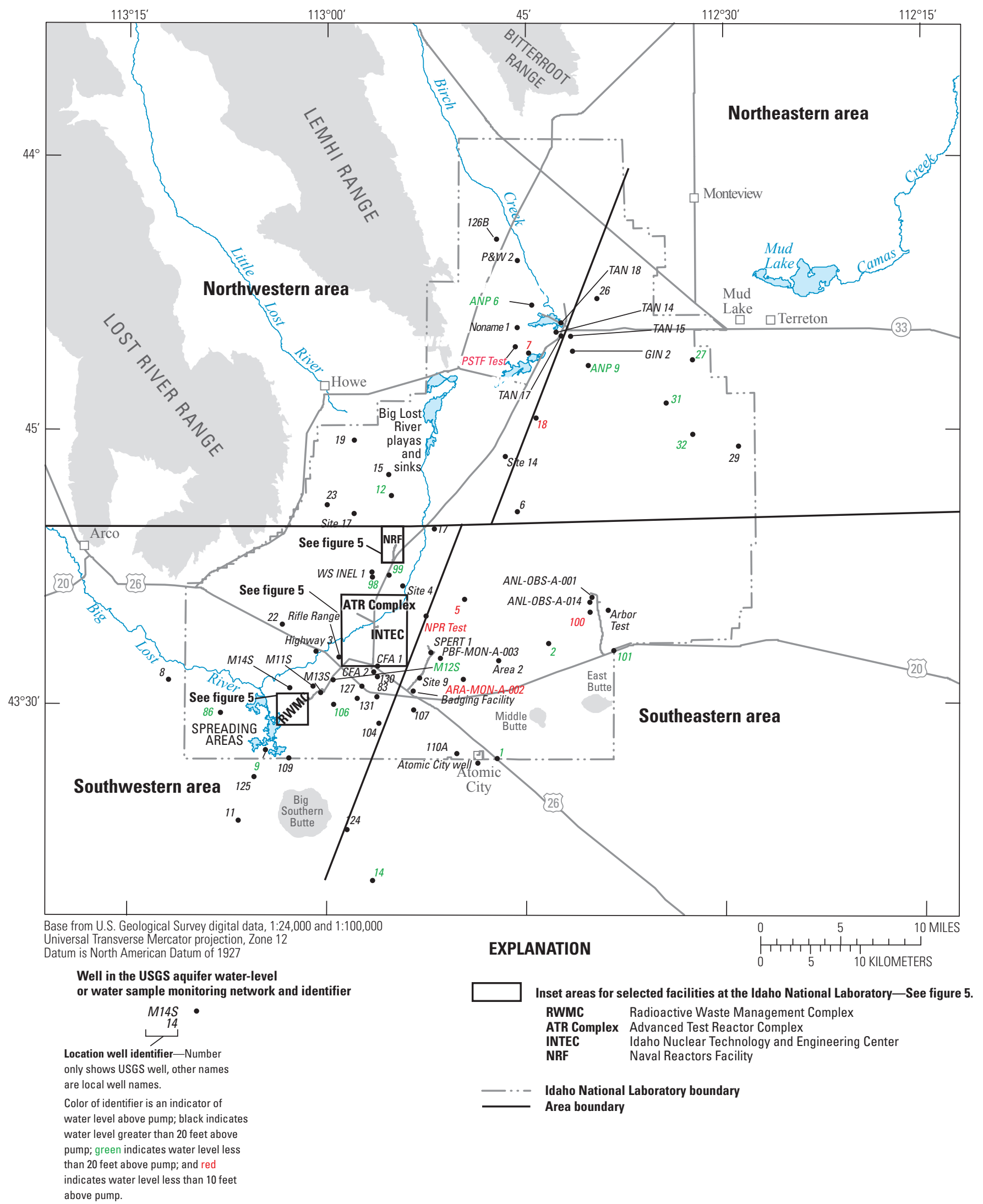

Figure 4. Water level above current pumps in wells at and near the Idaho National Laboratory, Idaho. 


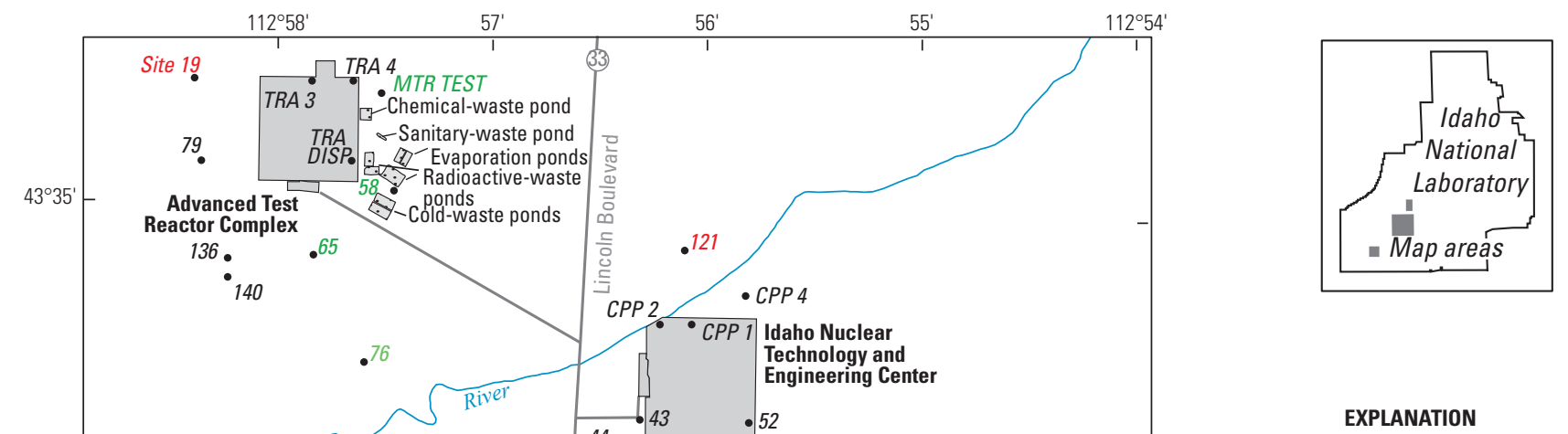

Well in the USGS aquifer water-level or water sample monitoring network and identifier

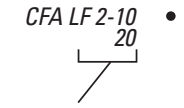

Location well identifier-Number only shows USGS well, other names are local well names.

Color of identifier is an indicator of water level above pump; black indicates water level greater than 20 feet above pump; green indicates water level less than 20 feet above pump; and red indicates water level less than 10 feet above pump.

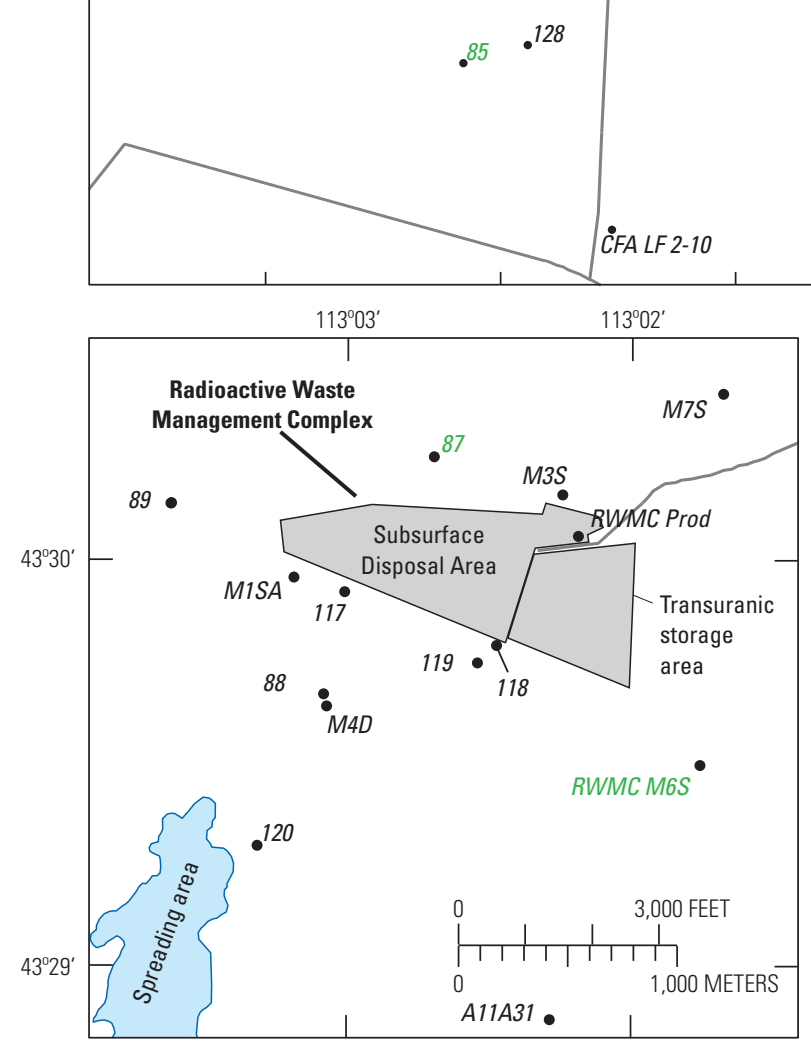

Base from U.S. Geological Survey digital data, 1:24,000 and 1:100,000 Universal Transverse Mercator projection, Zone 12

Datum is North American Datum of 1927

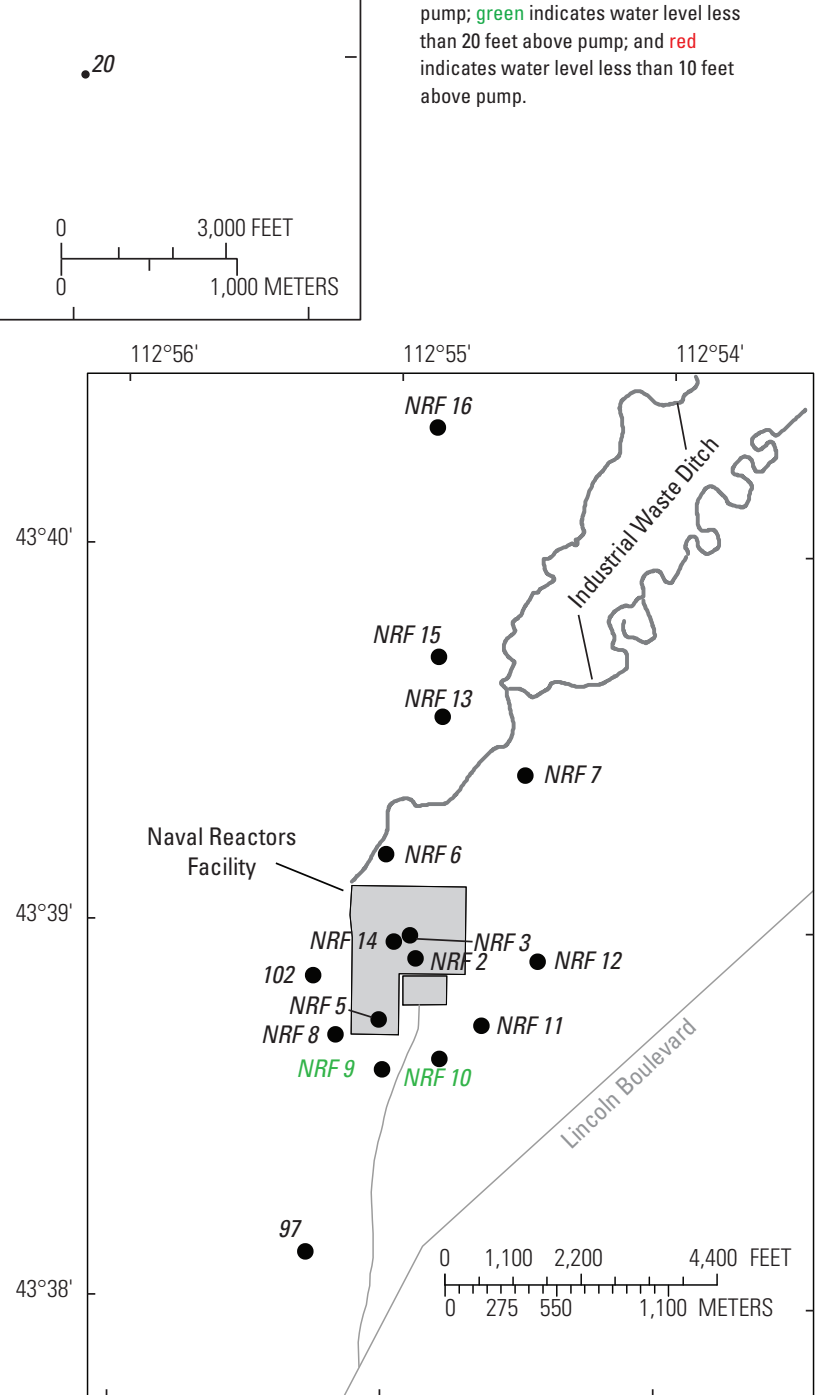

Figure 5. Water level above current pumps in wells near the Advanced Test Reactor Complex, the Idaho Nuclear Technology and Engineering Center, the Naval Reactors Facility, and the Radioactive Waste Management Complex, Idaho National Laboratory, Idaho. 


\section{Hydrologic Factors Affecting Water Levels in the Northeastern Area of the Idaho National Laboratory}

Busenberg and others (2001) used age-dating techniques of CFCs, sulfur hexafluoride, and tritium/helium to classify the water in the northeastern area of the INL based on the recharge type of the young fraction of groundwater. Based on their study, groundwater in the northeastern area of the INL is older, regional groundwater underflow that is mixed with local rapid, focused recharge; slow, diffuse areal recharge through the unsaturated zone; and agricultural return flow from the Mud Lake and Terreton areas (figs. 1 and 2). Water levels in this part of the INL are thus probably influenced by groundwater pumpage, agricultural return flow, some local precipitation, and wet and dry cycles affecting the regional flow pattern of the ESRP aquifer.

Hydrographs examined for northeastern wells suggest continued water-level decline with levels ranging approximately 24 and $35 \mathrm{ft}$ in wells USGS 21 and USGS 26, respectively (figs. $6 A$ and $6 B$ ). Water-level data for wells in the northeastern area show greater declines closer to the Mud Lake and Terreton areas (fig. 2). For example, wells USGS 26 and USGS 27 show water-level declines of about 25 and $20 \mathrm{ft}$ between 2000 and 2014, respectively; whereas, wells USGS 21 and USGS 32 show declines of about 18-20 ft, respectively (fig. 6). Wells to the north (USGS 26 and 27) seem to show a consistent decline since 2000, while the wells to the south (USGS 21 and 32) show declines until about 2005 and then begin to level off (except for the seasonal changes). One possible reason the northern wells show more decline as compared to the more southern wells could be related to irrigation practices upgradient of the wells. The northern wells are probably more influenced by irrigation in the Monteview/ Mud Lake area, which is primarily irrigated by groundwater diversions, whereas the more southern wells are influenced more by surface water diversions (less groundwater pumping) south of the Mud Lake/Terreton area (Spinazola, 1994, fig. 24; fig. 2).

Figure 7 illustrates the seasonal variability in wells USGS 21 and 27 in the northeastern area of the INL. The water-level hydrographs show that water levels increase during the autumn and winter following the growing season when pumping stops, and begin to decrease again in late April when pumping for irrigation resumes (figs. $7 D$ and $7 E$ ). Water levels continue to decline through September. Although seasonal changes occur in all the wells at the INL, the approximately $3-4.5 \mathrm{ft}$ seasonal change in wells USGS 21 and 27 (figs. 7D and 7E), along with other wells in the northeastern area of the INL (fig. 6), also reflects the effects of irrigation that are not as prevalent at other areas at the INL. Spinazola (1994, fig. 23) showed a recharge rate as high as 1.1 million acre-ft during 1984 in the irrigated areas northeast of the INL. Drawdown from groundwater pumping for irrigation also is prevalent northeast of the INL where total withdrawals increased from 240,000 acre-ft in 1983 to about 370,000 acre-ft in 1990 (Spinazola, 1994, fig. 31).

Geophysical and construction data for wells in the northeastern area of the INL that have less than $20 \mathrm{ft}$ of water above the pump intake (wells ANP 9, USGS 18, USGS 27, USGS 31, and USGS 32; table 2) are given in appendix A and figure 8 . Aquifer properties are interpreted using a suite of geophysical logs. Neutron logs are generally considered good indicators of saturated formation porosity (Hodges and others, 2012) and are used in conjunction with caliper logs (which can show borehole changes and in the case of basalt, fractures), gamma logs (which show the type of rock material), and gamma gamma (density) logs (which show the bulk density of the formation). Neutron logs are not available for all of these five wells in table 2 (Bartholomay, 1990, table 1), so geophysical information from well USGS 27 (fig. 8) was used as an indicator of aquifer properties near wells in the northeastern area of the INL. USGS 27 has its pump set at $262 \mathrm{ft}$ below land surface (BLS) and well logs and transmissivity for USGS 27 (fig. 8, table 4) indicate a moderately productive aquifer system, with similar density and neutron response from 240 to $285 \mathrm{ft} \mathrm{BLS}$. The density log (Bartholomay, 1990, p. 34) for USGS 18 shows thin layers of more dense and less dense material, between 290 and $310 \mathrm{ft}$ BLS, so it is believed that productivity for this well will be adequate as long as the water level is above the pump which is set at $301 \mathrm{ft} \mathrm{BLS} \mathrm{(table} \mathrm{2).} \mathrm{The} \mathrm{pump} \mathrm{is} \mathrm{set} \mathrm{at} 284 \mathrm{ft} \mathrm{BLS}$ in USGS 31, but no neutron or density logs are available so it is uncertain as to whether or not transmissivity will be maintained until the water level reaches the depth of the pump. The density log (Bartholomay, 1990, p. 49) for USGS 32 indicates low density material from 305 to $325 \mathrm{ft}$ BLS, so it is probable that transmissivity for this well will be maintained as long as the water level is above the pump which is set at $322 \mathrm{ft}$ BLS. The pump in ANP-9 is set at $262 \mathrm{ft}$ BLS and the density log for ANP-9 indicates mostly dense material from 245 to $265 \mathrm{ft}$ BLS (Bartholomay 1990, p. 183), so this well may not maintain the transmissivity as indicated by the aquifer test completed in 1990 (table 4) when the water level was $220 \mathrm{ft}$ BLS. 


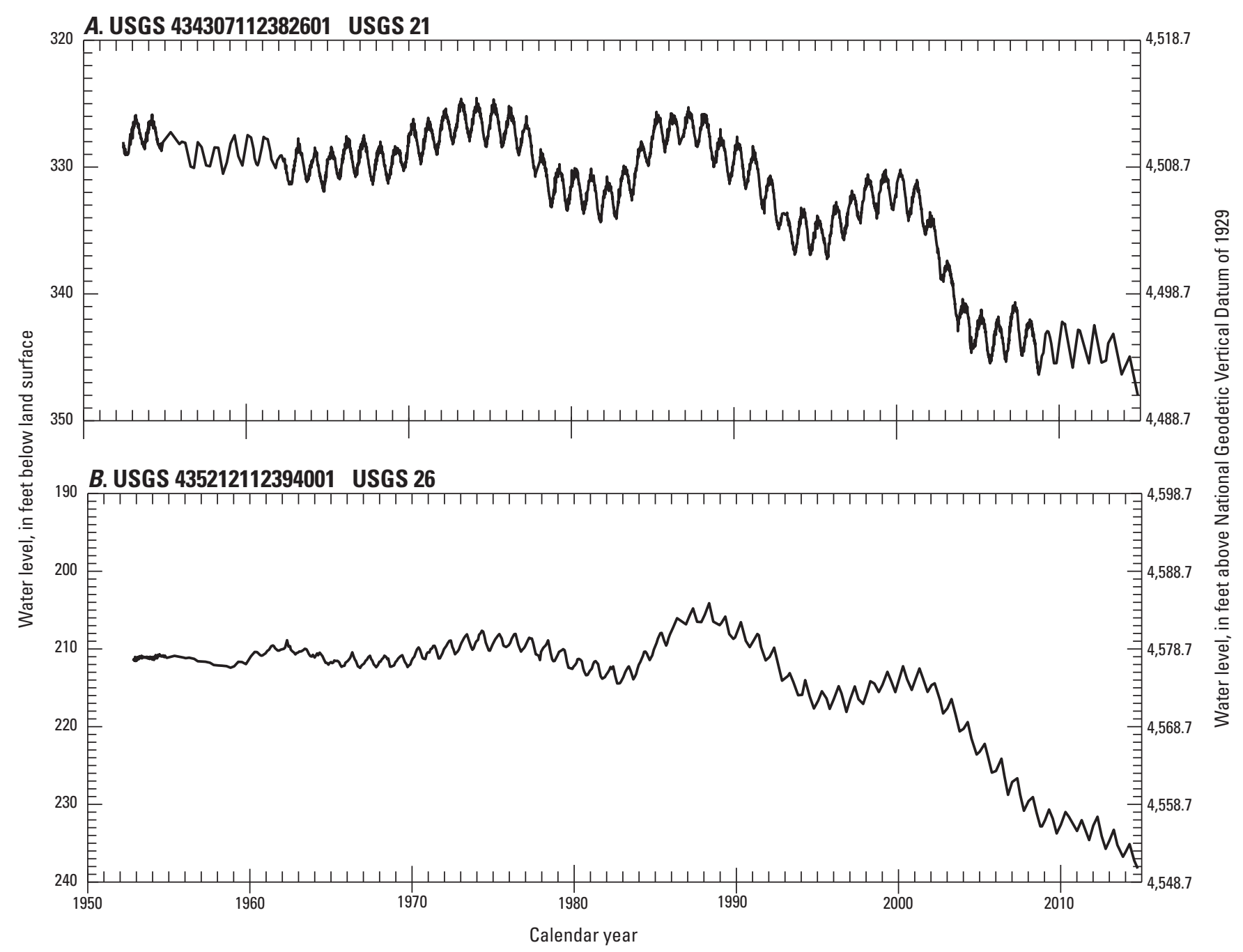

Figure 6. Water levels in wells (A) USGS 21, (B) USGS 26, (C) USGS 27, and (D) USGS 32 in the northeastern area of the Idaho National Laboratory, Idaho, 1952-2014. 


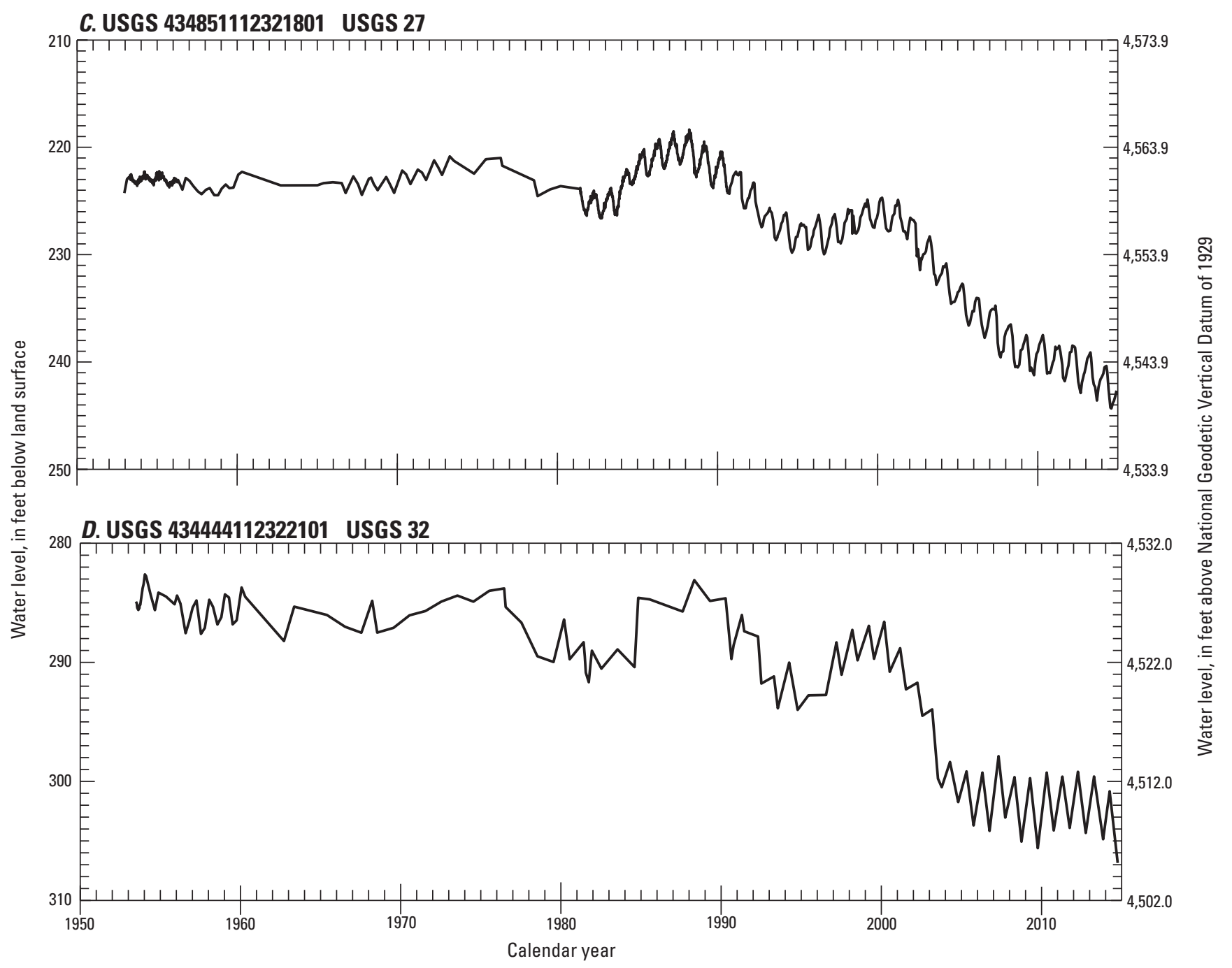

Figure 6.-Continued 


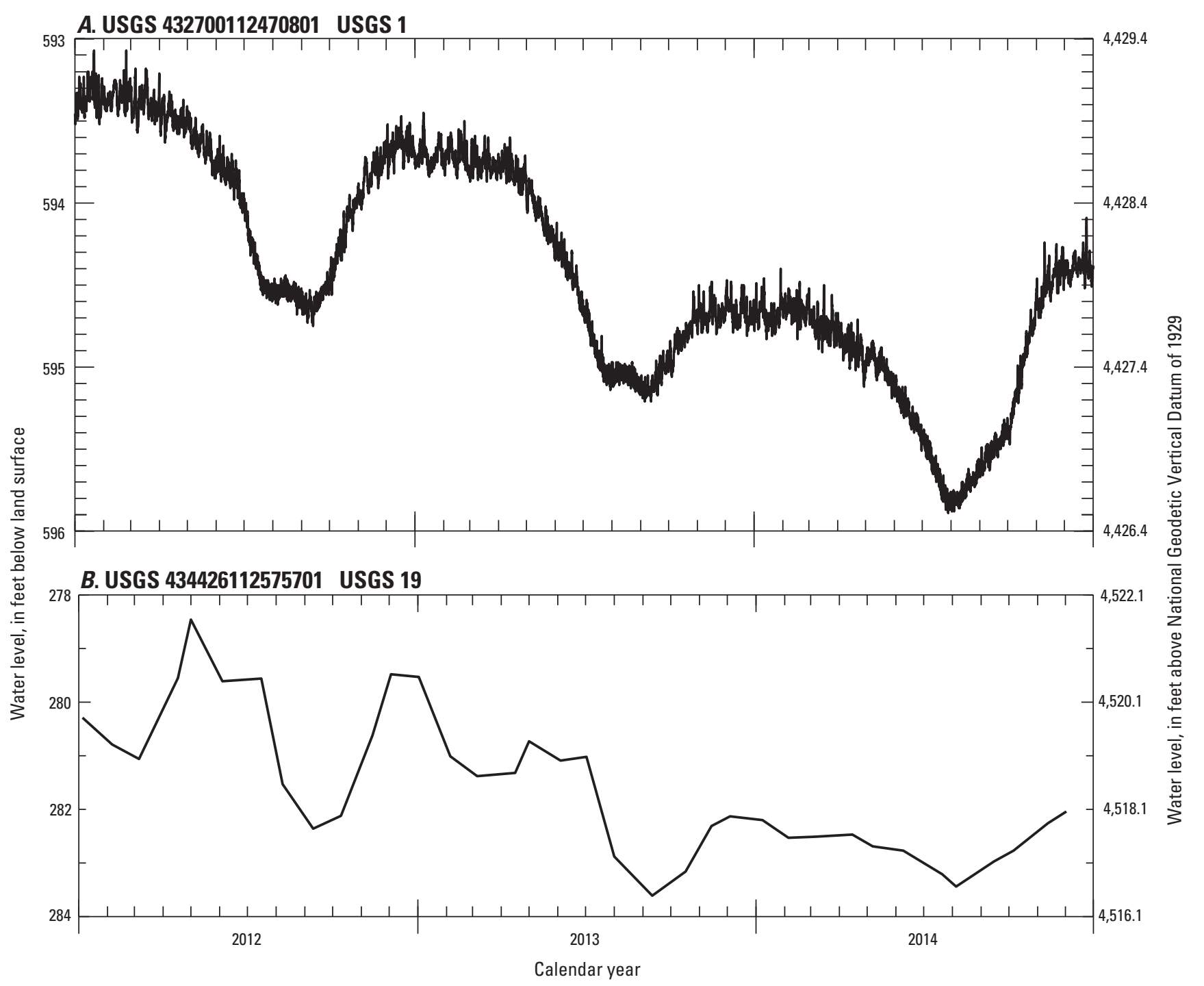

Figure 7. Water levels in wells (A) USGS 1, (B) USGS 19, (C) USGS 20, (D) USGS 21, and (E) USGS 27, Idaho National Laboratory, Idaho, 2012-2014. 


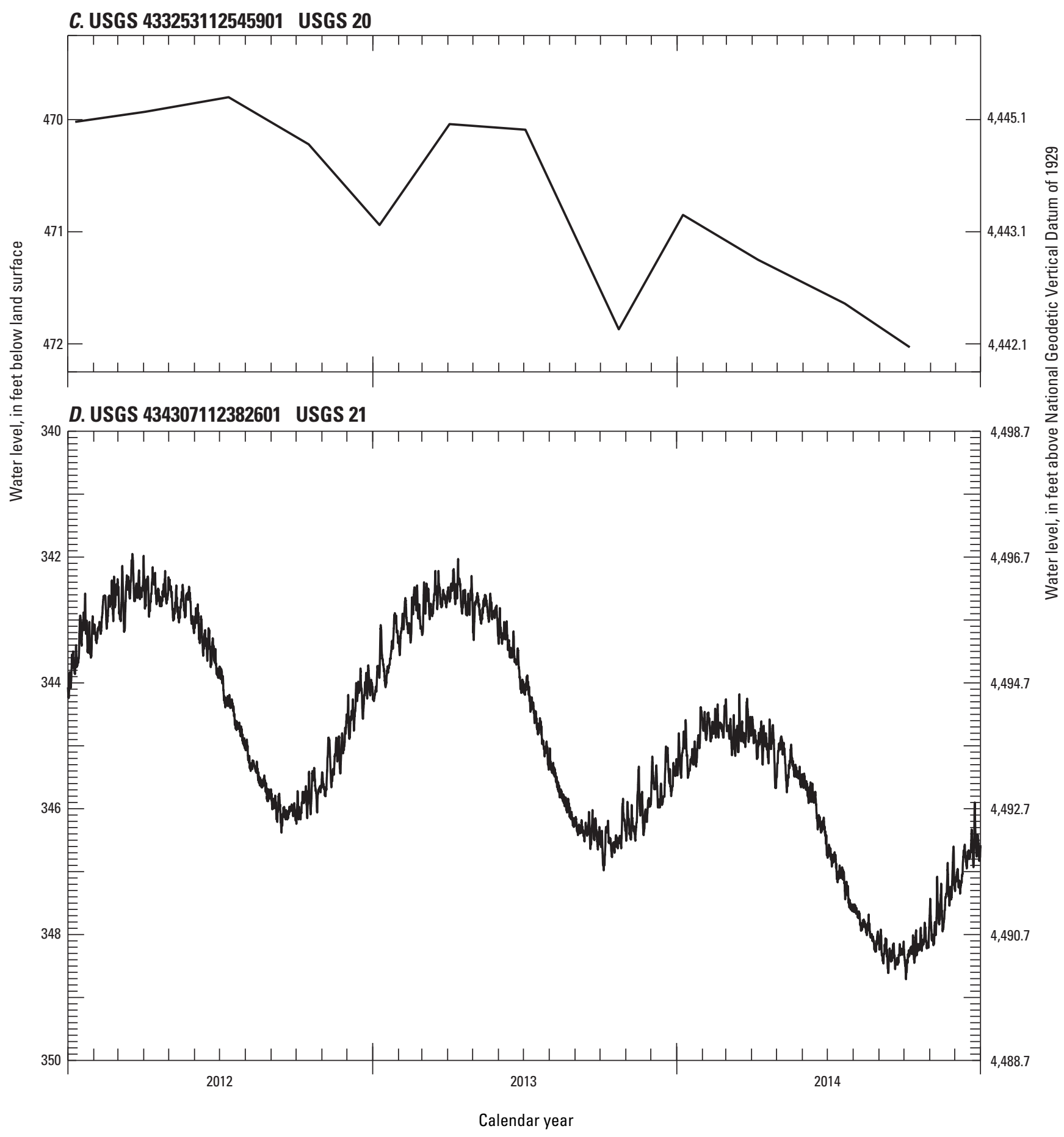

Figure 7.-Continued 


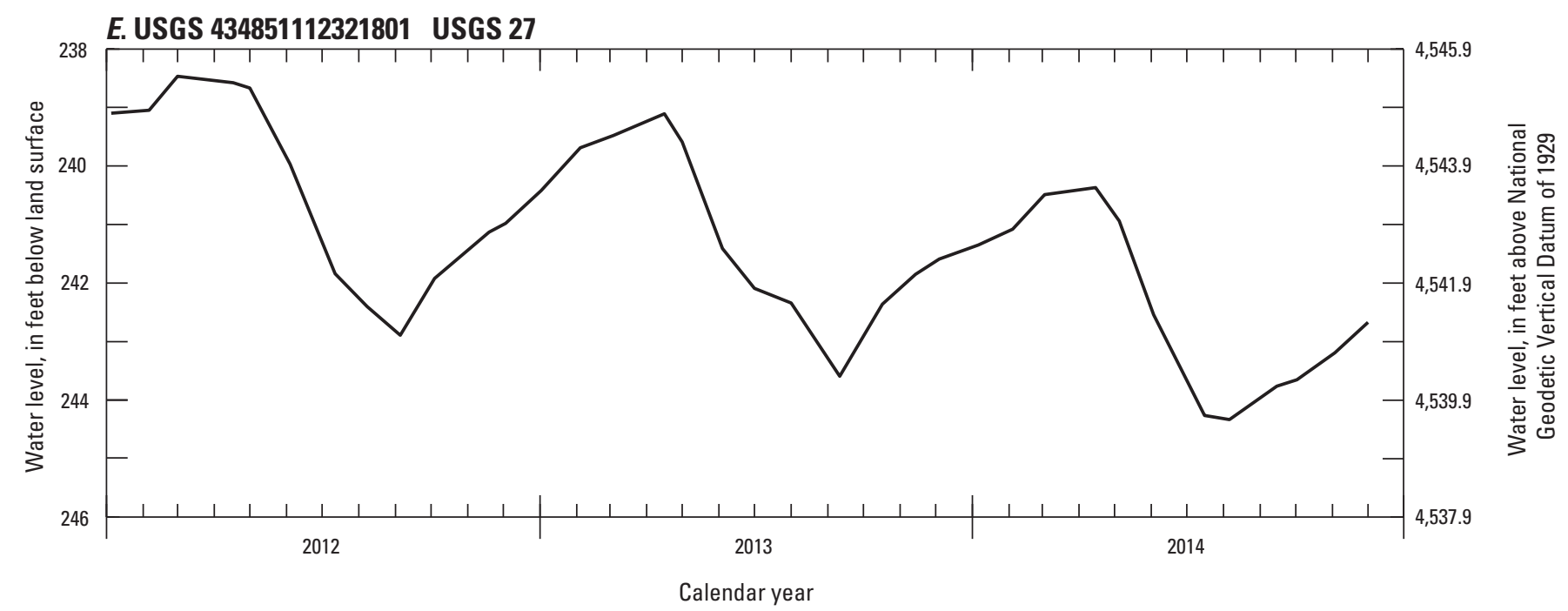

Figure 7.-Continued 
Results and Discussion

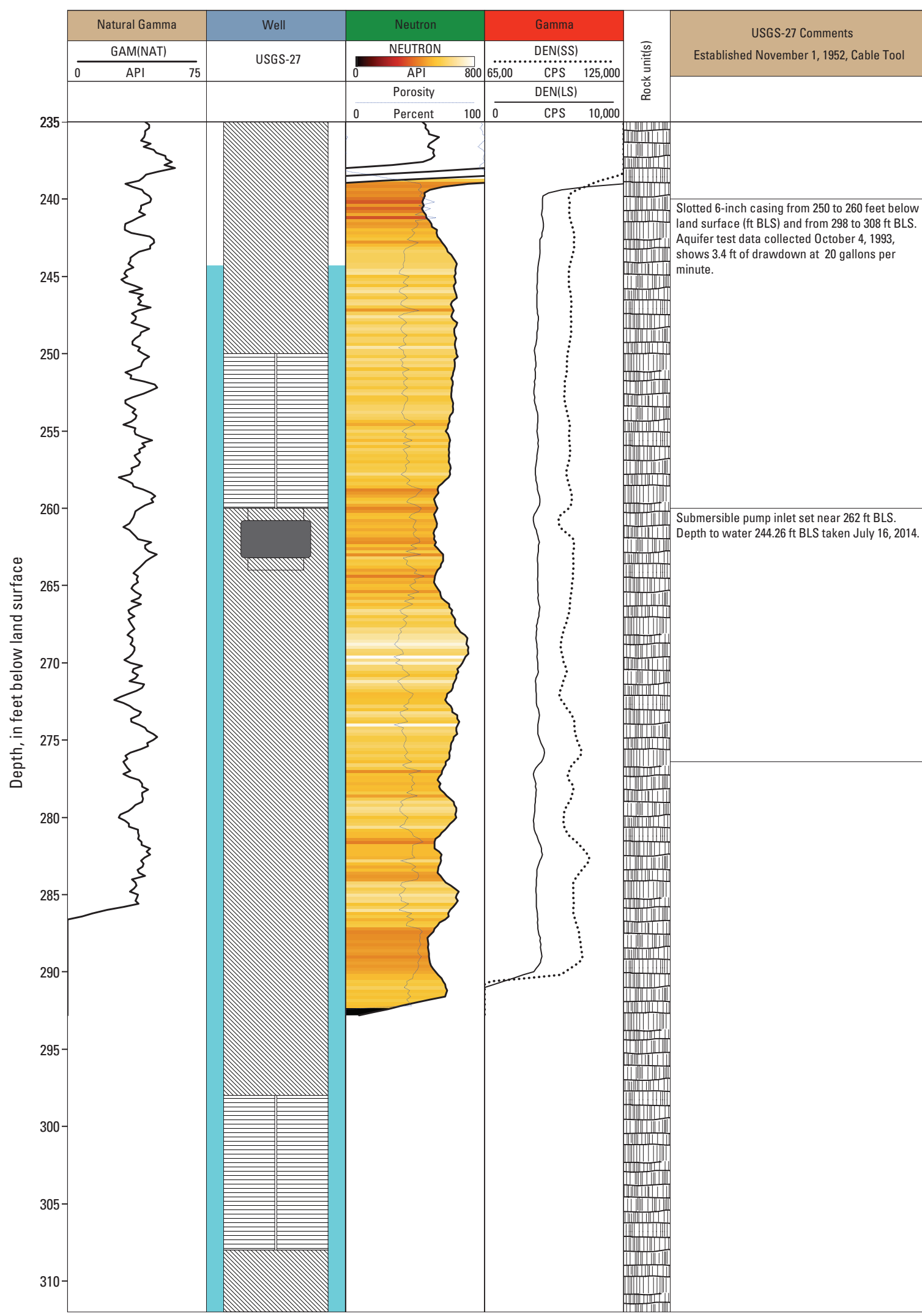

EXPLANATION

Definition of terms

API - American Petroleum Institute

CPS - counts per second

Den(SS) - short-spaced density

Den(LS) - long-spaced

density

Gam(Nat) - natural gamma

Neutron - hydrogen index

Rock units

BIIIIIIIIIIIIII Basalt

Well completion

Slotted casing

M.i...i.'. Cased interva

An.

Submersible

pump

Water level

Figure 8. Geophysical logs for wells USGS 27 and ANP-6 at the Idaho National Laboratory, Idaho. 


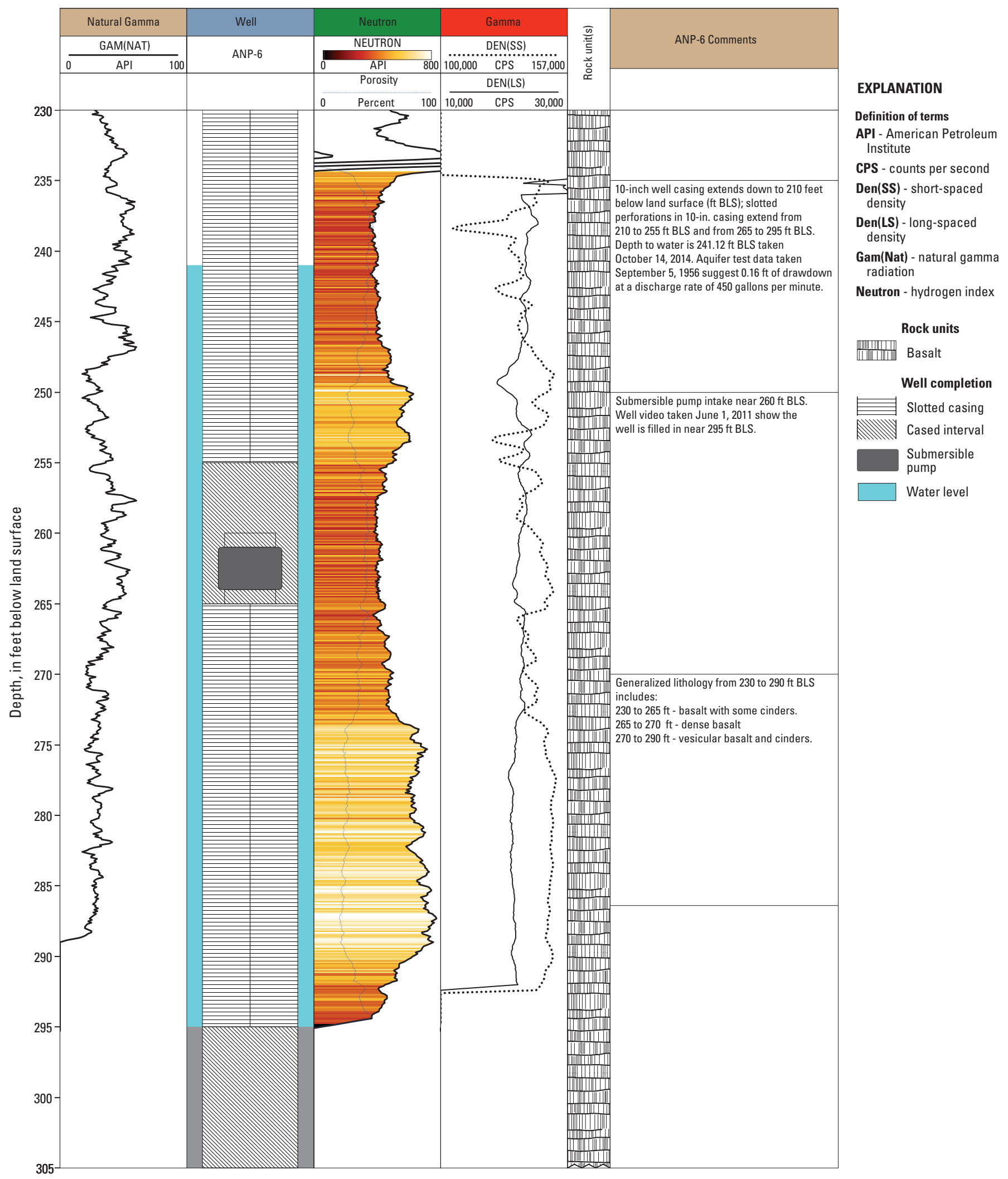

Figure 8.-Continued 
Table 4. Water level information and transmissivity information for wells with less than 20 feet of water above pump at the Idaho National Laboratory, Idaho.

[Location of wells is shown in figures 2 and 3. Water level measurements are given in feet with reference to National Geodetic Vertical Datum of 1929. Local name is the local well identifier used in this study. Site identifier is the unique numerical identifier used to access well data from the USGS National Water Information System (http://waterdata.usgs.gov/nwis). Transmissivity values are in foot squared per day ( $\left.\mathrm{ft}^{2} / \mathrm{d}\right)$ and were taken from Ackerman (1991) or Bartholomay and others (1997). Abbreviations: ft, feet; NA, not available; >, greater than]

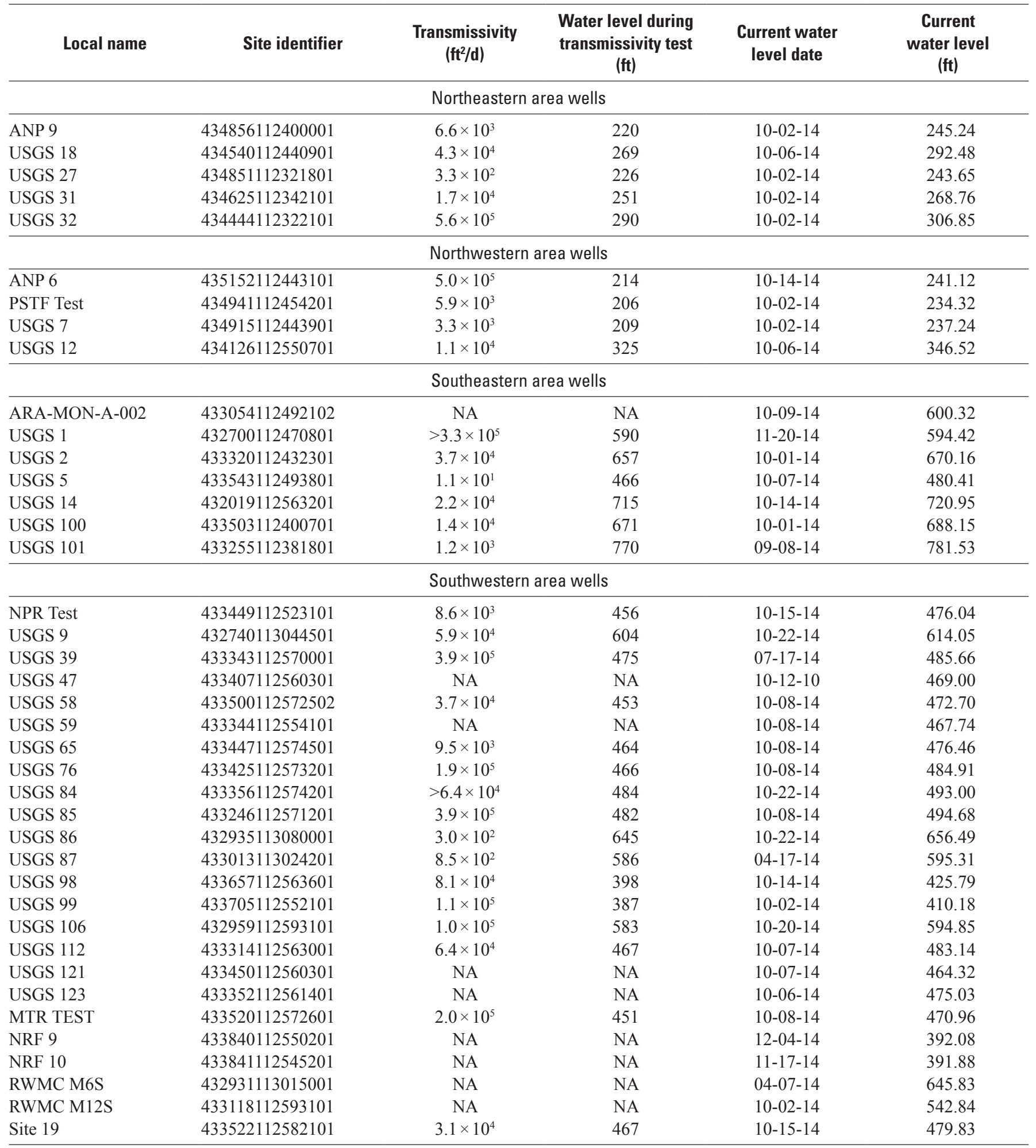


Hydrologic Factors Affecting Water Levels in the Northwestern Area of the Idaho National Laboratory

Busenberg and others (2001) used age-dating techniques of CFCs, sulfur hexafluoride, and tritium/helium to classify the water in the northwestern area of the INL based on the recharge type of the young fraction of groundwater. Water in the northwestern area of the INL is characterized as a mixture of old and young water derived from Birch Creek, Little Lost River, and Big Lost River surface water and groundwater underflow. Wells completed in the northwest area (fig. 2) suggest water-level data is impacted by mountain front underflow, flow from the Little Lost River and Birch Creek, and episodic flow events within the Big Lost River.

Groundwater in USGS 12, near the Big Lost River, indicates water-level change that appears to be strongly influenced by flow in the Big Lost River (Bennett, 1990, p. 31; Bartholomay and others, 2012, fig. 8). Furthermore, water levels in USGS 12 have fluctuated approximately $40 \mathrm{ft}$ over the period of record, peaking in the early 1970s and reaching a low during 2014. Water levels reported for USGS 12 appear to fluctuate based on the amount of flow in the Big Lost River (figs. 9B and 10); furthermore, the ESRP aquifer near USGS 12 appears to be directly affected by water table mounding when Big Lost River flow occurs (Ackerman and others, 2006). Water levels in USGS 19 (fig. 9C) show some variability similar to USGS 12 in terms of wet and dry cycles. Water levels have declined about $34 \mathrm{ft}$ from a high in the early 1980s; but, given its location, the well is most likely influenced by recharge from the Little Lost River Basin. Seasonal effects influence water levels in this well, with seasonal variability (1.5-4 ft fluctuation seasonally in the past three years; fig. 7D) similar to wells in the northeast. Water levels in wells northwest of TAN indicate ongoing declines since about 2000, similar to patterns reported for wells USGS 26 and USGS 27 described for the northeastern area. For example, water levels in USGS 25 (fig. 9D) show about 26-ft decline in the past 14 years.

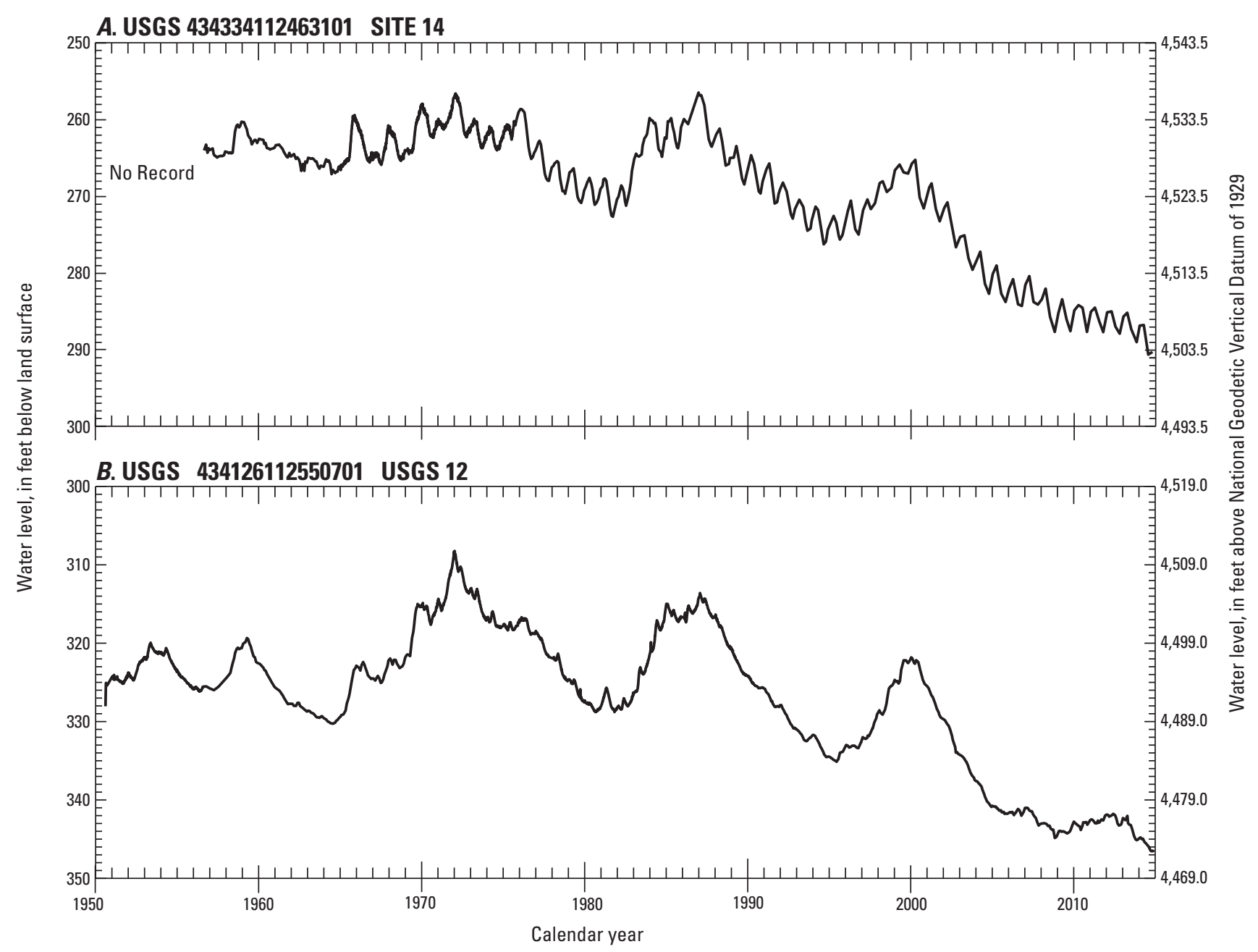

Figure 9. Water levels in wells (A) Site 14, (B) USGS 12, (C) USGS 19, and (D) USGS 25 in the northwestern part of the Idaho National Laboratory, Idaho, 1950-2014. 
C. USGS 434426112575701 USGS 19

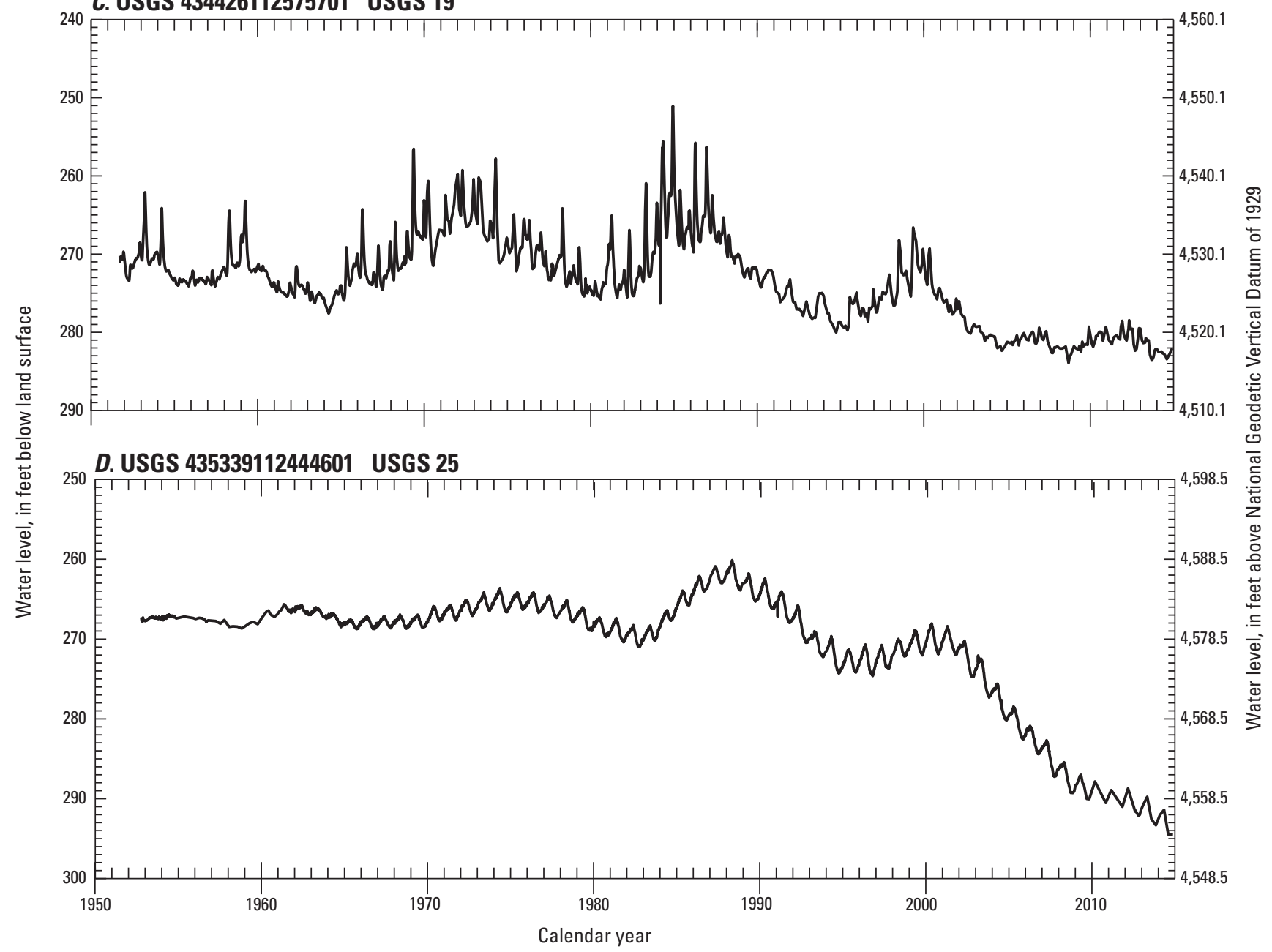

Figure 9.-Continued

Robertson and others (1974, appendix A) indicated that well USGS 25 probably represents natural conditions of the northeastern area that are not influenced by irrigation, and noted that this well may be influenced by Birch Creek flow because its water level only fluctuated by about $3 \mathrm{ft}$ from 1952 to 1968. More recently, use of water coming from Birch Creek may be affecting larger water-level decline in that only about 5 percent diversion return occurs from a hydroelectric project that started in 1987 to trenches in the northern part of the INL (Swanson and others, 2003). The most recent declines in well USGS 25 also show strong seasonal effects that probably indicate irrigation influence, and the declining levels for the past 14 years probably are related to the same hydrologic factors that are affecting wells USGS 26 and 27 to the east. Well Site 14 southwest of TAN also shows this similar declining trend and seasonal fluctuations (fig. 9A). Water levels in the northwestern area of the INL are thus probably impacted by irrigation pumpage, wet and dry cycles, along with the lack of more recent recharge from the Big Lost River, Little Lost River, and Birch Creek (depending on the location of the well in the basin).

Geophysical and well data for wells in the northwestern area of the INL that have $20 \mathrm{ft}$ or less of water above the pump include ANP 6, PSTF Test, USGS 7, and USGS 12 (table 2; fig. 8; appendix A). Not all of the four wells have neutron logs available (Bartholomay, 1990, table 1), so geophysical information from well ANP-6 (fig. 8B) was used to represent aquifer properties near wells in the northwestern part of the INL. Well logs for ANP-6 (fig. 8) indicate a mostly productive aquifer system, with a dense, possibly less productive zone (poorer neutron response) between about 248 and $253 \mathrm{ft}$ BLS. The neutron and density response for material right above the pump, which is set at $260 \mathrm{ft} \mathrm{BLS}$, is probably adequate for good production, so it is believed that the productivity will not change as long as the water level is above the pump. 
The density log (Bartholomay, 1990, p. 296) for PSTF Test (pump setting of $242 \mathrm{ft}$ BLS, table 2) indicates material with similar density from 210 to $245 \mathrm{ft} \mathrm{BLS}$, so it is believed that the transmissivity of this well will not change much as water levels decline. The density log for USGS 7 (Bartholomay, 1990, p. 23), which has its pump set at $242 \mathrm{ft}$ BLS, indicates low density material from 210 to $245 \mathrm{ft} \mathrm{BLS}$, so it is believed that the productivity of this well will not change much as water levels decline. The density log for USGS 12 (Bartholomay, 1990, p. 27), which has the pump set at $358 \mathrm{ft}$ BLS, indicates low density material from 325 to $355 \mathrm{ft} \mathrm{BLS}$, suggesting that the productivity of this well will not change much as water levels decline.
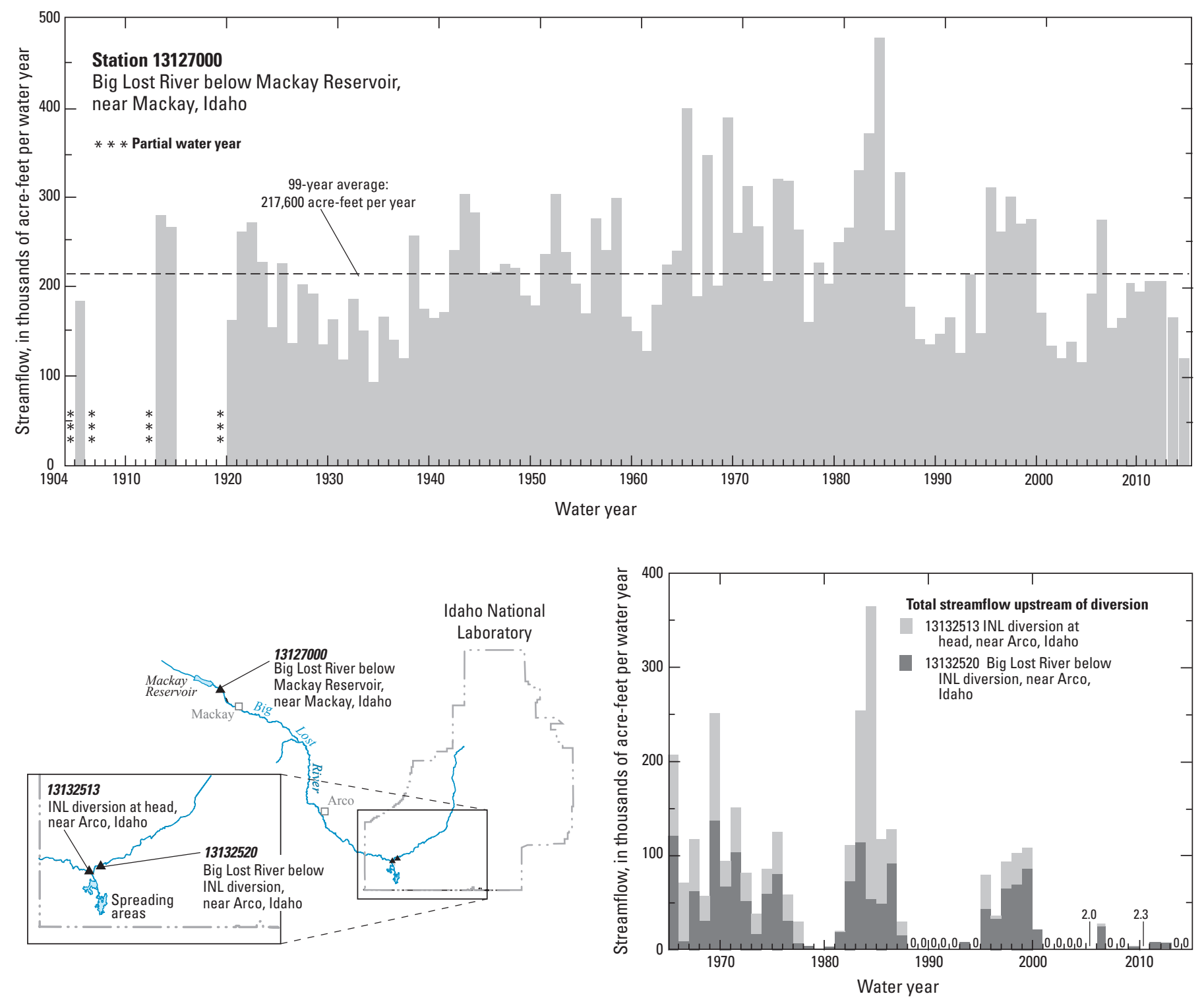

Figure 10. Streamflow at U.S. Geological Survey streamgaging stations along the Big Lost River: Big Lost River below Mackay Reservoir, near Mackay, Idaho, water years 1905, 1913-14, and 1920-2014; Big Lost River below the Idaho National Laboratory (INL) diversion, near Arco; and INL diversion at head, near Arco, Idaho, water years 1965-2014. 


\section{Hydrologic Factors Affecting Water Levels in the Southeastern Area of the Idaho National Laboratory}

Busenberg and others (2001) used age dating techniques of CFCs, sulfur hexafluoride, and tritium/helium to classify the water in the southeastern area of the INL based on the recharge type of the young fraction of groundwater. Water in the southeastern area of the INL is old, regional groundwater underflow that is mixed with young water derived from local rapid, focused recharge, probably from precipitation infiltration. Water levels in this part of the INL are thus probably influenced by some local precipitation, but mostly from wet and dry cycles affecting the regional aspect of the ESRP aquifer.
Hydrographs for wells in the southeastern area (USGS 1, USGS 2, USGS 5 and Highway 2; fig. 11) show much less decline in overall water levels than in other parts of the INL. Declines from highest recorded water levels to lowest levels range from about $14 \mathrm{ft}$ in USGS 1 to about $20 \mathrm{ft}$ in Highway 2 (fig. $11 B$ and $11 A$, respectively). Wells in the southeastern area generally show consistent changes that correspond to wet and dry climate cycles, and they all show a decline from 2000 to about 2005 and relatively stable levels since 2005 . This area of the ESRP aquifer does not appear to show effects related to irrigation, with the exception of the Highway 2 well. Most of these wells also show much less seasonal variation. For example, USGS 1 only shows a maximum of about a $1.5 \mathrm{ft}$ change seasonally during the past 3 years (fig. $7 A$ ).

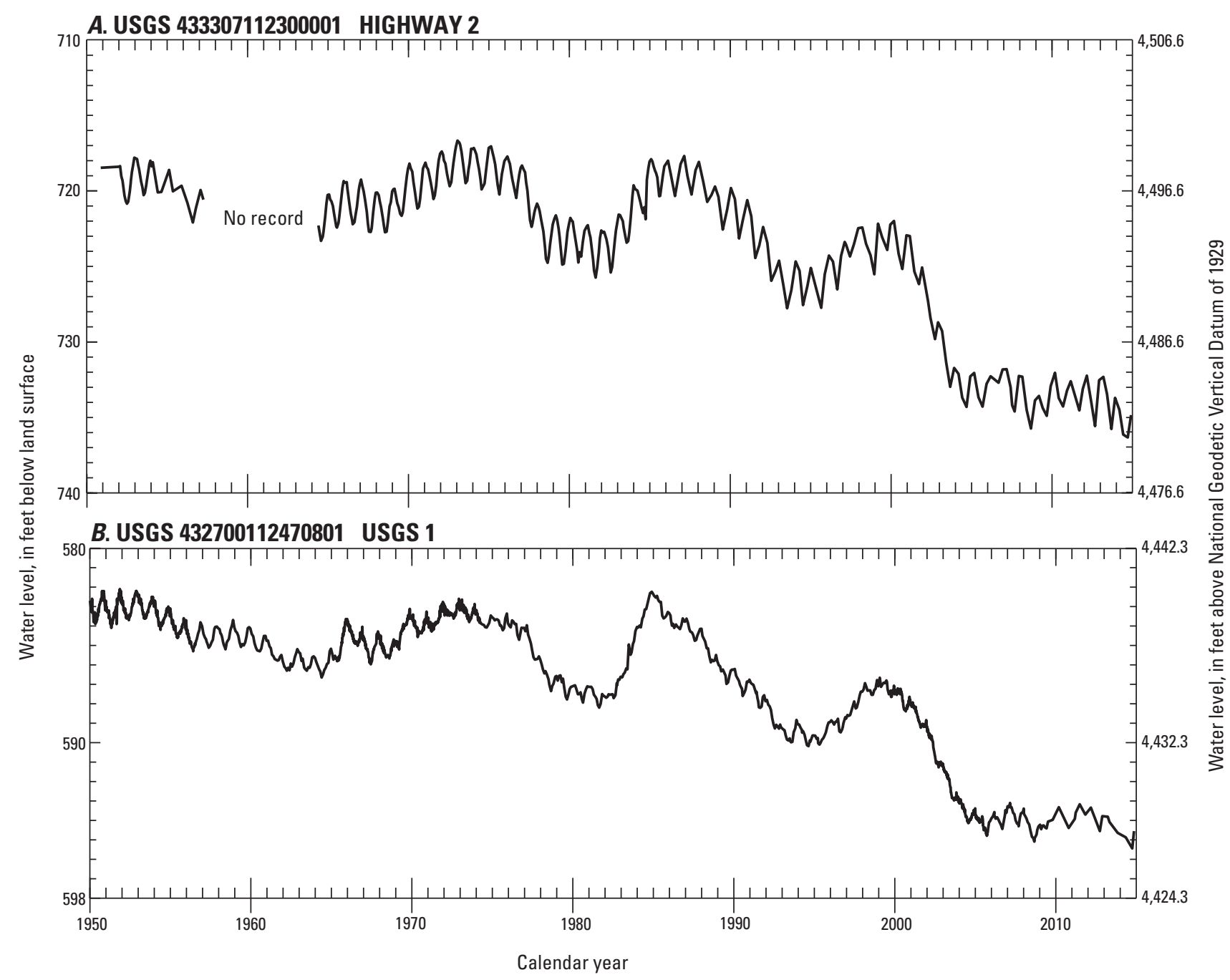

Figure 11. Water levels in wells $(A)$ Highway 2, (B) USGS 1, $(C)$ USGS 2, and $(D)$ USGS 5 in the southeastern area of the Idaho National Laboratory, Idaho, 1949-2014. 


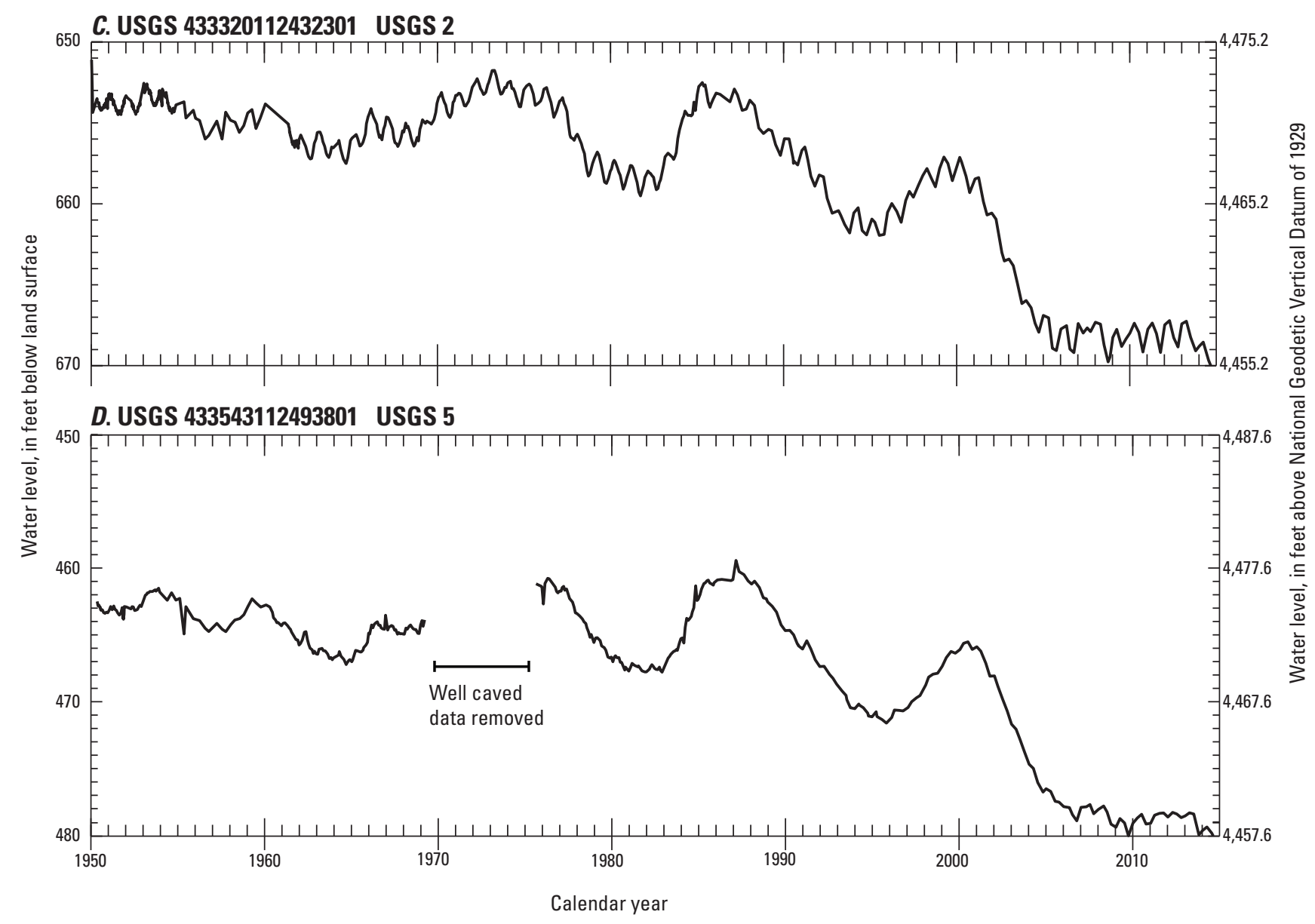

Figure 11.-Continued 
Geophysical logs for wells with less than $20 \mathrm{ft}$ of water above the pump (wells ARA-MON-A-002, USGS 1, USGS 2, USGS 5, USGS 14, USGS 100, and USGS 101; table 2) are given in appendix A. Neutron logs (appendix A) for ARA-MON-A-002 from about 600 to about $615 \mathrm{ft} \mathrm{BLS} \mathrm{show}$ good productive basalt units, so this well should produce water until the water level declines below the pump that is set at $604 \mathrm{ft} \mathrm{BLS}$. The density and neutron logs for USGS 1 (appendix A) show mostly less dense material and productive basalt between 595 and $615 \mathrm{ft}$ BLS, so it is believed that productivity for this well will be adequate as long as the water level is above the pump that is set at $612 \mathrm{ft} \mathrm{BLS}$. The neutron log for USGS 2 indicates a good productive zone from about 677 to about $682 \mathrm{ft}$ BLS. The pump is set at about $685 \mathrm{ft}$ BLS, and productivity could decline drastically if the water level declines below $682 \mathrm{ft}$ BLS. USGS 5 is completed in dense basalt with interbedded sediment and exhibits low transmissivity, so water production will continue to be poor from this well until water levels decline below the pump. The neutron log for USGS 14 (appendix A) indicates a good productive zone between about 725 and $740 \mathrm{ft}$ BLS, so this well should maintain its productivity at its current pump setting of $739 \mathrm{ft}$ BLS. Neutron and density logs (Bartholomay, 1990 , p. 135) for USGS 100 indicate that this well should remain productive until water levels decline below the pump. The pump in USGS 101 is set at $800 \mathrm{ft}$ BLS in basalt below a sediment layer that recently has been sluffing into the well. The USGS tried to pull the pump to clean out the sediment, but sediment above the pump prevented removal. When the pump in this well eventually fails, the well may need to be abandoned.

\section{Hydrologic Factors Affecting Water Levels in the Southwestern Area of the Idaho National Laboratory}

Busenberg and others (2001) used age-dating techniques of CFCs, sulfur hexafluoride, and tritium/helium to classify the water in the southwestern area of the INL based on the recharge type of the young fraction of groundwater. Water in the southwestern area of the INL is characterized as a mixture of old and young water derived from Birch Creek, Little Lost River, and Big Lost River surface-water and groundwater underflow.

Wells constructed in the southwestern area (fig. 2) suggest that well location has a direct effect on water levels and annual fluctuations. Wells closest to the Big Lost River show more water-level change than wells located farther from the Big Lost River (Davis and others, 2013, fig. 11). For example, well MTR Test, located about 1 mi north of the Big Lost River, shows a water-level decline of about $23 \mathrm{ft}$ from the 1980s to 2014 (fig. 12A), whereas USGS 104, located about $8 \mathrm{mi}$ southeast of the Big Lost River, only shows a decline of about $14 \mathrm{ft}$ for the same period (fig. 12E). The wells in the southwest do show similar patterns of water-level fluctuations with increases and decreases related to wet and dry cycles (fig. 12). Wells in the southwest show large declines starting in 2000 to about 2005 and show a relative leveling off since 2005 (fig. 12) similar to wells in the southeast. Additionally, wells in the southwest and southeast show less seasonal variability (about 1-2 ft change in USGS 20 and USGS 1, respectively, fig. 7) than wells to the northwest and northeast; this low variability is attributed to lack of influence from irrigation pumpage.

Well USGS 9 shows a large 13-ft increase in its water level from 1980 to 1984 (fig. 12C); Ackerman and others (2006) attributed this spike to flow into the spreading areas south of the RWMC (fig. 1). This spike corresponds with more than 450,000 acre-ft of discharge into the spreading areas during the 1983 and 1984 water years (fig. 10). USGS 8 shows a similar increase in the same time period (fig. 11). The rise in water level in well USGS 9 from 1994 to 2000 was $4.5 \mathrm{ft}$ when about 80,000 acre-ft discharge occurred into the spreading areas (fig. 10), while the rise in wells farther north near the Big Lost River (MTR Test and USGS 97) showed water-level rises of 8 to $10 \mathrm{ft}$ in the same time period. This is probably due to larger amounts of discharge along the Big Lost River (about 280,000 acre-ft total flow during 1995-99 water years) versus discharge into the spreading areas (fig. 12).

Geophysical and well data on wells in the southwestern area of the INL that have less than $20 \mathrm{ft}$ of water still above the pump (wells USGS 9, USGS 39, USGS 47, USGS 58-59, USGS 65, USGS 76, USGS 84-87, USGS 98-99, USGS 106, USGS 112, USGS 121, USGS 123, MTR Test, NPR Test, NRF-9, NRF-10, RWMC M6S, RWMC M12S, and Site 19; table 2) are given in appendix A. Most of the wells have neutron and density logs available (appendix A). Wells USGS 9, USGS 47, USGS 58-59, USGS 65, USGS 84, USGS 87, USGS 99, USGS 106, USGS 112, MTR Test, and NPR Test (Bartholomay, 1990; appendix A) indicate mostly low-density material and good neutron response for the aquifer material between the current pump setting and current water level (table 2), so productivity is expected to be maintained until the water level declines below the pump. Wells 76, 85, 86 , and Site 19 indicate mostly low-density aquifer material (Bartholomay, 1990) between the current pump setting and current water level, so productivity should stay about the same until the water level declines below the pump. For well USGS 39, the water level declined below the pump in 2014, and the well is caved in below the current pump setting, so this well can no longer be monitored until the water level rises again. For well USGS 98, logs indicate that the pump is set (440 ft BLS) in a sediment layer, so productivity could change when the water level declines near the current pump setting. 


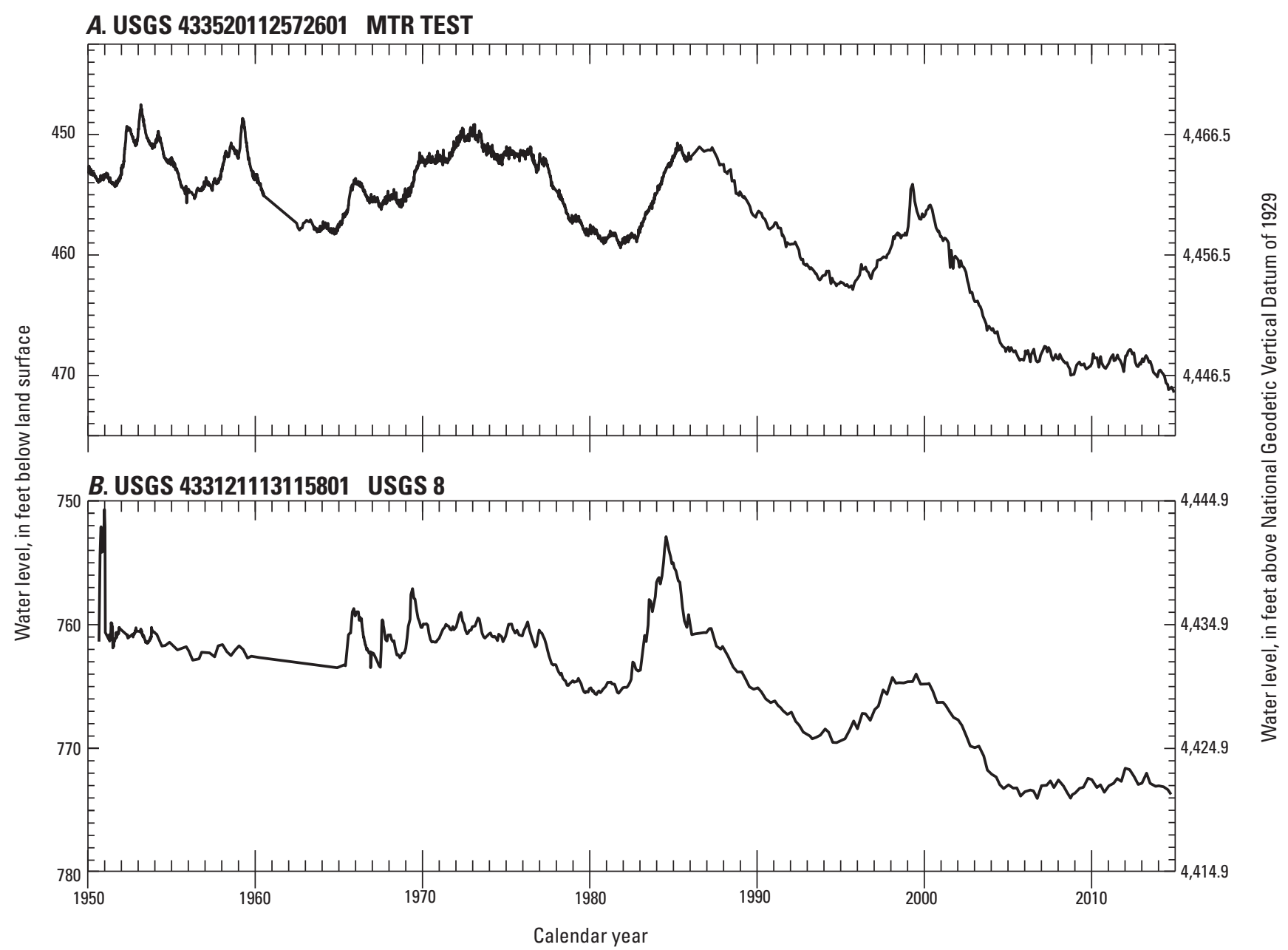

Figure 12. Water levels in wells (A) MTR Test, $(B)$ USGS 8, (C) USGS 9, (D) USGS 20, (E) USGS 97, and (F) USGS 104 in the southwestern area of the Idaho National Laboratory, Idaho, 1949-2014. 


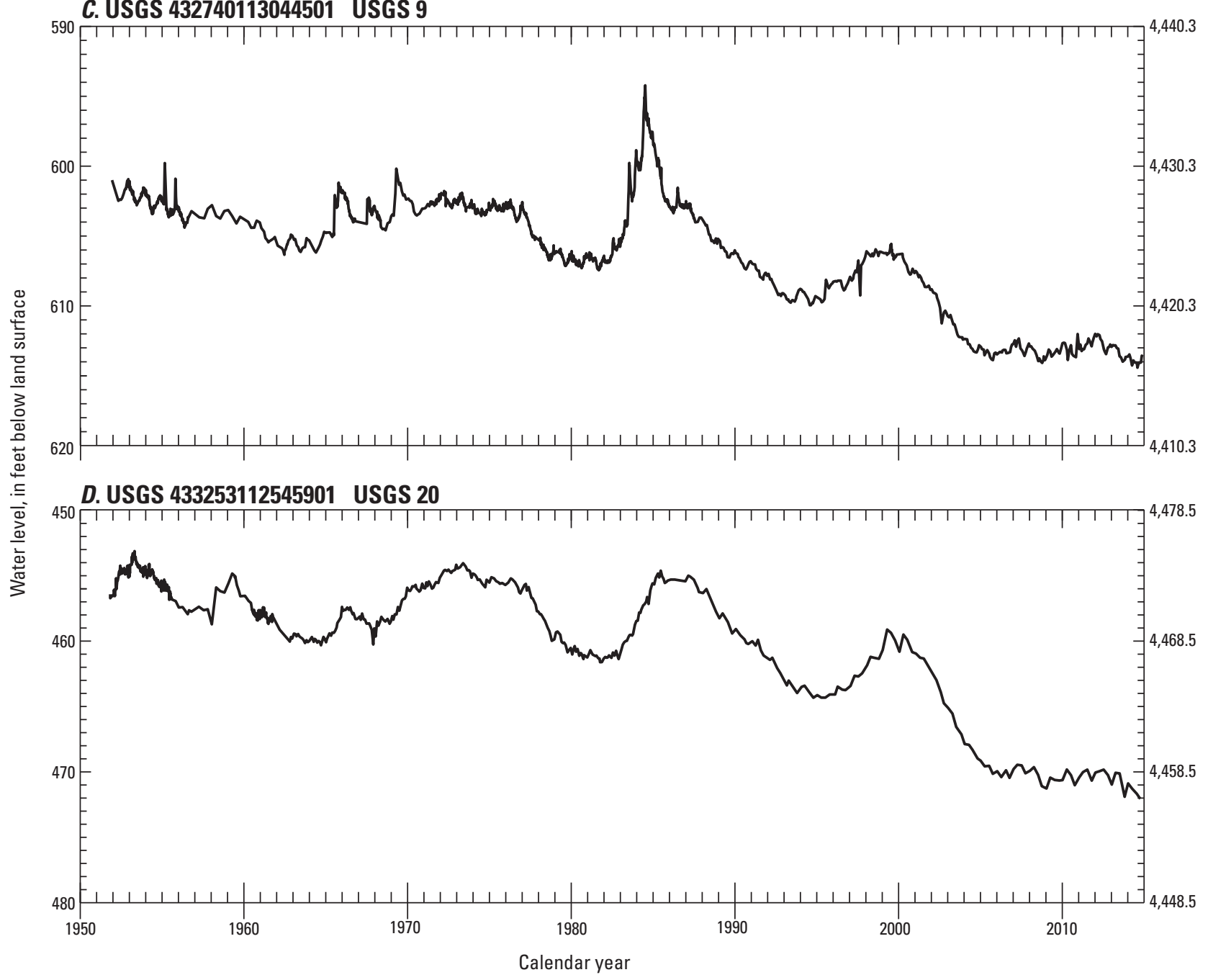

Figure 12.-Continued 


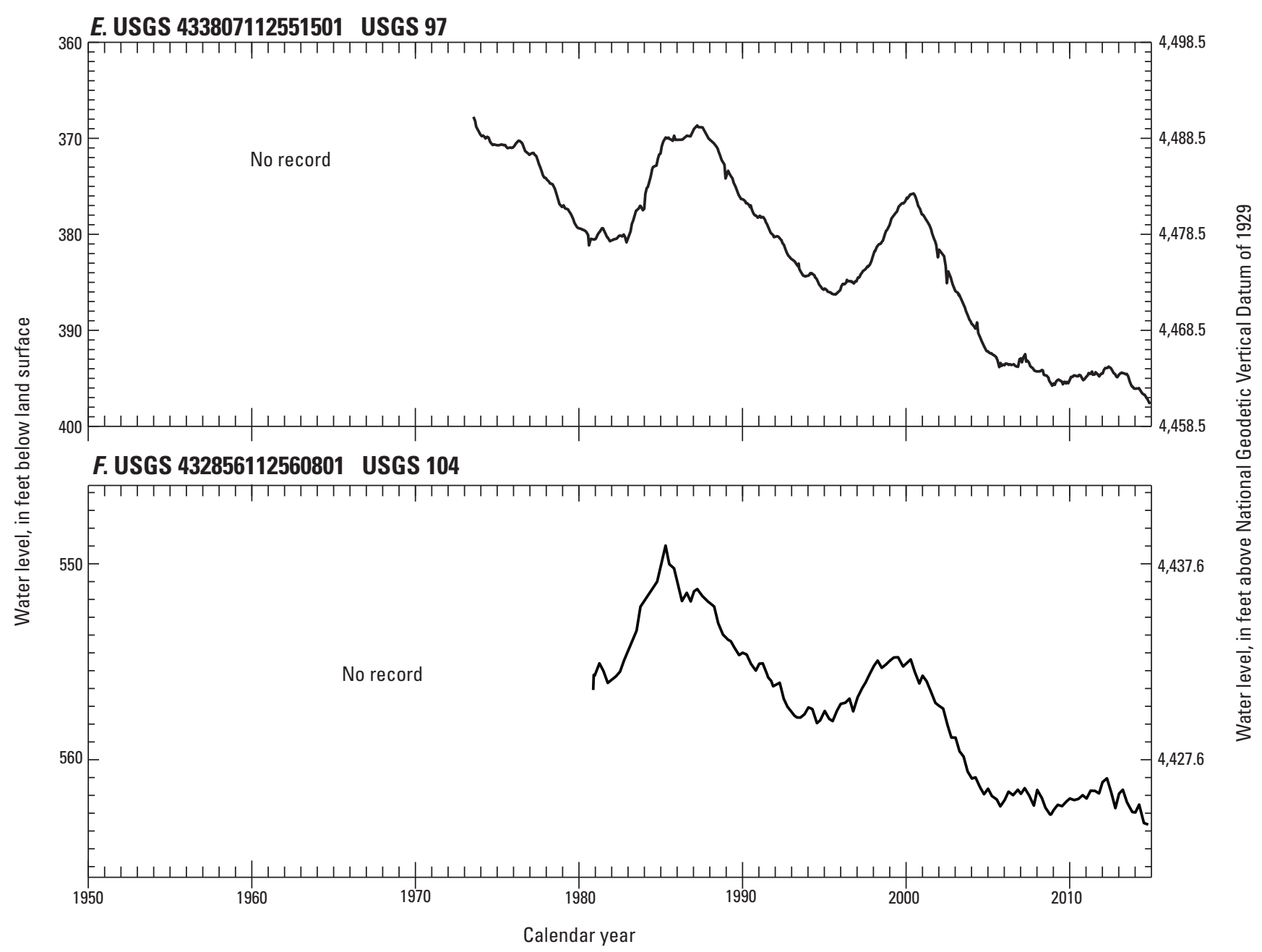

Figure 12.-Continued 


\section{Summary and Conclusions}

The U.S. Geological Survey (USGS), in cooperation with the U.S. Department of Energy, has maintained a waterlevel monitoring program at the Idaho National Laboratory (INL) since 1949 to systematically measure water levels to provide long-term information on groundwater recharge, discharge, movement, and storage in the eastern Snake River Plain (ESRP) aquifer. Water levels are collected continuously, monthly, quarterly, semi-annually, or annually depending on historical data, research needs, and changes in the hydrograph.

During 2014, water levels in the ESRP aquifer at the INL reached all-time lows for the period of record. Water levels from selected wells at the INL were evaluated to assess how future water-level declines will affect well productivity. Water levels were compared with pump depth to determine the hydraulic head above the pumps. Geophysical logs were examined for selected wells to evaluate long-term productivity as water levels decline towards the depth of the pumps. Hydrologic factors affecting water levels in different areas of the INL were examined to provide an understanding of why water-level declines and fluctuations occur.

Water levels were evaluated on their geographical distribution at the INL based on northeastern, northwestern, southeastern, and southwestern areas. The eastern and western areas were divided along a line similar to water types defined as eastern regional underflow and western tributary recharge. The northern and southern areas were based on an arbitrarily defined line.

In the northeastern area, five wells were identified as having less than 20 feet (ft) of water remaining above the pump. Water levels in northeastern wells show water-level fluctuations as much as $4.5 \mathrm{ft}$ seasonally and have shown declines as much as $25 \mathrm{ft}$ in the past 14 years. These declines are attributed to groundwater pumping for irrigation and the lack of a wet hydrologic cycle. Water levels in the northernmost wells of the northeastern area show more consistent declines in the past 14 years compared to the southernmost wells that show declines to about 2005 and then a relatively stable hydrograph. The larger declines in the northernmost wells are attributed to more groundwater use for irrigation in the upgradient area of the aquifer.

In the northwestern area, four wells were identified as having less than $20 \mathrm{ft}$ of water remaining above the current pump setting. Water levels in northwestern wells show water-level fluctuations based on the location of the well in the basin. Well USGS 12 near the Big Lost River Sinks shows consistent changes based on surface-water flow in the Big Lost River, showing increases when the Big Lost River flows and large declines when no flow occurs for several years. Well USGS 19 shows water-level fluctuations related to wet and dry cycles and shows some seasonality related to irrigation practices in the Little Lost River Basin. Wells in the northern part of the northwestern area show similar water-level changes as wells in the north-northeast area, and the recent declines are attributed to groundwater irrigation northwest of Mud Lake.

In the southeastern area, seven wells were identified as having less than $20 \mathrm{ft}$ of water remaining above the pump. Most of the wells in the southeast show less decline during the period of record compared with wells to the northeast, and the smaller declines are attributed to less influence from irrigation practices. Most of the wells also show only about a 1-2 ft change seasonally because they are not influenced as much by irrigation.

In the southwestern area, 24 wells were identified as having less than $20 \mathrm{ft}$ of water remaining above the pump. Wells in the southwest also only show small 1-2 ft changes seasonally because of a lack of irrigation influence. Wells show more fluctuation in water levels the closer they are to the Big Lost River, and levels fluctuate with wet and dry cycles of recharge.

Geophysical log data indicate that most of the wells will maintain their current level of water production until the water levels decline near their pump settings. A few of the wells may change from being high productivity to low productivity when the water level gets within $5 \mathrm{ft}$ from the top of the pump. Areas most susceptible to another drought cycle are wells in the northeast and northwest.

\section{References Cited}

Ackerman, D.J., 1991, Transmissivity of the Snake River Plain aquifer at the Idaho National Engineering Laboratory, Idaho: U.S. Geological Survey Water-Resources Investigations Report 91-4058 (DOE/ID-22097), 35 p.

Ackerman, D.J., Rattray, G.W., Rousseau, J.P., Davis, L.C., and Orr, B.R., 2006, A conceptual model of ground-water flow in the eastern Snake River Plain aquifer at the Idaho National Laboratory and vicinity with implications for contaminant transport: U.S. Geological Survey Scientific Investigations Report 2006-5122 (DOE/ID-22198), 62 p. [Also available at http://pubs.usgs.gov/sir/2006/5122/.]

Ackerman, D.J., Rousseau, J.P., Rattray, G.W., and Fisher, J.C., 2010, Steady-state and transient models of groundwater flow and advective transport, Eastern Snake River Plain aquifer, Idaho National Laboratory and vicinity, Idaho: U.S. Geological Survey Scientific Investigations Report 2010-5123 (DOE/ID-22209), 220 p. [Also available at http://pubs.usgs.gov/sir/2010/5123/.]

Barraclough, J.T., Bagby, J.C., White, L.J., and Jensen, R.G., 1984, Water-level data for selected wells on or near the Idaho National Engineering Laboratory, 1949 through 1982: U.S. Geological Survey Open-File Report 84-239 (DOE/ ID-22065), 343 p. 
Barraclough, J.T., and Jensen, R.G., 1976, Hydrologic data for the Idaho National Engineering Laboratory site, Idaho, 1971 to 1973: U.S. Geological Survey Open-File Report 75-318 (IDO-22055), $52 \mathrm{p}$.

Barraclough, J.T., Lewis, B.D., and Jensen, R.G., 1981, Hydrologic conditions at the Idaho National Engineering Laboratory, Idaho, emphasis 1974-1978: U.S. Geological Survey Water-Resources Investigations Open-File Report 81-526 (IDO-22060), 116 p.

Barraclough, J.T., Robertson, J.B., and Janzer, V.J., 1976, Hydrology of the solid waste burial ground, as related to the potential migration of radionuclides, Idaho National Engineering Laboratory, with a section on drilling and sample analyses, by L.G. Saindon: U.S. Geological Survey Open-File Report 76-471 (IDO-22056), 183 p.

Barraclough, J.T., Teasdale, W.E., and Jensen, R.G., 1967a, Hydrology of the National Reactor Testing Station, Idaho, 1965: U.S. Geological Survey Open-File Report (IDO22048), $107 \mathrm{p}$.

Barraclough, J.T., Teasdale, W.E., Robertson, J.B., and Jensen, R.G., 1967b, Hydrology of the National Reactor Testing Station, Idaho, 1966: U.S. Geological Survey Open-File Report 67-12 (IDO-22049), 95 p.

Bartholomay, R.C., 1990, Digitized geophysical logs for selected wells on or near the Idaho National Engineering Laboratory, Idaho: U.S. Geological Survey Open-File Report 90-366 (DOE/ID-22088), 347 p.

Bartholomay, R.C., Davis, L.C., Fisher, J.C., Tucker, B.J., and Raben, F.A., 2012, Water-quality characteristics and trends for selected sites at and near the Idaho National Laboratory, Idaho, 1949-2009: U.S. Geological Survey Scientific Investigations Report 2012-5169 (DOE/ID-22219), 68 p. plus appendixes. [Also available at http://pubs.usgs.gov/ $\operatorname{sir} / 2012 / 5169 /$.

Bartholomay, R.C., Maimer, N.V., and Wehnke, A.J., 2014, Field methods and quality-assurance plan for water-quality activities and water-level measurements, U.S. Geological Survey, Idaho National Laboratory, Idaho: U.S. Geological Survey Open-File Report 2014-1146 (DOE/ID-22230), 66 p. [Also available at http://pubs.usgs.gov/of/2014/1146/.]

Bartholomay, R.C., Orr, B.R., Liszewski, M.J., and Jensen, R.G., 1995, Hydrologic conditions and distribution of selected radiochemical and chemical constituents in water, Snake River Plain aquifer, Idaho National Engineering Laboratory, Idaho, 1989 through 1991: U.S. Geological Survey Water-Resources Investigations Report 95-4175 (DOE/ID-22123), 47 p.
Bartholomay, R.C., Tucker, B.J., Ackerman, D.J., and Liszewski, M.J., 1997, Hydrologic conditions and distribution of selected radiochemical and chemical constituents in water, Snake River Plain aquifer, Idaho National Engineering Laboratory, Idaho, 1992 through 1995: U.S. Geological Survey Water-Resources Investigations Report 97-4086 (DOE/ID-22137), 57 p. [Also available at http://pubs.er.usgs.gov/publication/ wri974086.]

Bartholomay, R.C., Tucker, B.J., Davis, L.C., and Green, M.R., 2000, Hydrologic conditions and distribution of selected constituents in water, Snake River Plain aquifer, Idaho National Engineering and Environmental Laboratory, Idaho, 1996 through 1998: U.S. Geological Survey WaterResources Investigations Report 00-4192 (DOE/ID-22167), 52 p. [Also available at http://pubs.er.usgs.gov/publication/ wri004192.]

Bennett, C.M., 1990, Streamflow losses and ground-water level changes along the Big Lost River at the Idaho National Engineering Laboratory, Idaho: U.S. Geological Survey Water-Resources Investigations Report 90-4067 (DOE/ ID-22091), $49 \mathrm{p}$.

Busenberg, Eurybiades, Plummer, L.N., and Bartholomay, R.C., 2001, Estimated age and source of the young fraction of groundwater at the Idaho National Engineering and Environmental Laboratory: U.S. Geological Survey Water-Resources Investigations Report 01-4265 (DOE/ID-22177), 144 p.

Cecil, L.D., Welhan, J.A., Green, J.R., Frape, S.K., and Sudicky, E.R., 2000, Use of chlorine-36 to determine regional-scale aquifer dispersivity, eastern Snake River Plain aquifer, Idaho/USA: Nuclear Instruments and Methods in Physics Research Section B 172, p. 679-687.

Davis, L.C., 2006, An update of hydrologic conditions and distribution of selected constituents in water, Snake River Plain aquifer, Idaho National Laboratory, Idaho, emphasis 1999-2001: U.S. Geological Survey Scientific Investigations Report 2006-5088 (DOE/ID-22197), 48 p. [Also available at http://pubs.er.usgs.gov/publication/ sir20065088.]

Davis, L.C., 2008, An update of hydrologic conditions and distribution of selected constituents in water, Snake River Plain aquifer and perched-water zones, Idaho National Laboratory, Idaho, emphasis 2002-05: U.S. Geological Survey Scientific Investigations Report 2008-5089 (DOE/ ID-22203), 74 p. [Also available at http://pubs.er.usgs.gov/ publication/sir20085089.] 
Davis, L.C., 2010, An update of hydrologic conditions and distribution of selected constituents in water, Snake River Plain aquifer and perched groundwater zones, Idaho National Laboratory, Idaho, emphasis 2006-08: U.S. Geological Survey Scientific Investigations Report 2010 5197 (DOE/ID-22212), 80 p. [Also available at http://pubs. er.usgs.gov/publication/sir20105197.]

Davis, L.C., Bartholomay, R.C., and Rattray, G.W., 2013, An update of hydrologic conditions and distribution of selected constituents in water, eastern Snake River Plain aquifer and perched groundwater zones, Idaho National Laboratory, Idaho, emphasis 2009-11: U.S. Geological Survey Scientific Investigations Report 2013-5214 (DOE/ID-22226), 90 p. [Also available at http://dx.doi. org/10.3133/sir20135214]

Duke, C.L., Roback, R.C., Reimus, P.W., Bowman, R.S., McLing, T.L., Baker, K.E., and Hull, L.C., 2007, Elucidation of flow and transport processes in a variably saturated system of interlayered sediment and fractured rock using tracer tests: Vadose Zone Journal, v. 6, no. 4, p. $855-867$.

Fisher, J.C., 2013, Optimization of water-level monitoring networks in the eastern Snake River Plain aquifer using a kriging-based genetic algorithm method: U.S. Geological Survey Scientific Investigations Report 2013-5120 (DOE/ ID-22224), 74 p. [Also available at http://pubs.usgs.gov/ $\operatorname{sir} / 2013 / 5120 /$.

Fisher, J.C., Rousseau, J.P., Bartholomay, R.C., and Rattray, G.W., 2012, A comparison of U.S. Geological Survey threedimensional model estimates of groundwater source areas and velocities to independently derived estimates, Idaho National Laboratory and vicinity, Idaho: U.S. Geological Survey Scientific Investigations Report 2012-5152 (DOE/ ID-22218), $130 \mathrm{p}$.

Garabedian, S.P., 1986, Application of a parameter-estimation technique to modeling the regional aquifer underlying the eastern Snake River Plain, Idaho: U.S. Geological Survey Water Supply Paper 2278, 60 p.

Hodges, M.K.V., Orr, S.M., Potter, K.E., and LeMaitre, Tynan, 2012, Construction diagrams, geophysical logs, and lithologic descriptions for boreholes USGS 103, 105, 108, 131, 135, NRF-15, and NRF-16, Idaho National Laboratory, Idaho: U.S. Geological Survey Data Series 660 (DOE/ ID-22217), 34 p. [Also available at http://pubs.usgs.gov/ ds/660/.]

Lewis, B.D., and Jensen, R.G., 1985, Hydrologic conditions at the Idaho National Engineering Laboratory, Idaho, 1979-1981 update: U.S. Geological Survey Hydrologic Investigations Atlas HA674, 2 sheets. [Also available at http://pubs.er.usgs.gov/publication/ha674.]
Mann, L.J., 1986, Hydraulic properties of rock units and chemical quality of water for INEL1 - A 10,365-foot deep test hole drilled at the Idaho National Engineering Laboratory, Idaho: U.S. Geological Survey Water-Resources Investigations Report 86-4020 (DOE/ID-22070), 23 p.

Mann, L.J., and Beasley, T.M., 1994, Iodine-129 in the Snake River Plain aquifer at the Idaho National Engineering Laboratory, Idaho, 1990-1991: U.S. Geological Survey Water-Resources Investigations Report 94-4053 (DOE/ ID-22115), $27 \mathrm{p}$.

Morris, D.A., Barraclough, J.T., Chase, G.H., Teasdale, W.E., and Jensen, R.G., 1965, Hydrology of subsurface waste disposal, National Reactor Testing Station, Idaho, annual progress report, 1964: U.S. Atomic Energy Commission, Idaho Operations Office Publication, IDO-22047-USGS, $186 \mathrm{p}$.

Morris, D.A., Barraclough, J.T., Hogenson, G.M., Shuter, Eugene, Teasdale, W.E., Ralston, D.A., and Jensen, R.G., 1964, Hydrology of subsurface waste disposal, National Reactor Testing Station, Idaho, annual progress report, 1963: U.S. Atomic Energy Commission, Idaho Operations Office Publication, IDO-22046-USGS, 97 p.

Morris, D.A., Hogenson, G.M., Shuter, Eugene, and Teasdale, W.E., 1963, Hydrology of waste disposal, National Reactor Testing Station, Idaho, annual progress report, 1962: U.S. Atomic Energy Commission, Idaho Operations Office Publication, IDO-22044-USGS, 99 p.

Nimmo, J.R., Perkins, K.S., Rose, P.A., Rousseau, J.P., Orr, B.R., Twining, B.V., and Anderson, S.R., 2002, Kilometerscale rapid transport of naphthalene sulfonate tracer in the unsaturated zone at the Idaho National Engineering and Environmental Laboratory: Vadose Zone Journal, v. 1, issue 1, p. 89-101.

Olmsted, F.H., 1962, Chemical and physical character of ground water in the National Reactor Testing Station, Idaho: U.S. Atomic Energy Commission, Idaho Operations Office Publication IDO-22043-USGS, 142 p.

Orr, B.R., and Cecil, L.D., 1991, Hydrologic conditions and distribution of selected chemical constituents in water, Snake River Plain aquifer, Idaho National Engineering Laboratory, Idaho, 1986 to 1988: U.S. Geological Survey Water-Resources Investigations Report 91-4047 (DOE/ ID-22096), 56 p. [Also available at http://pubs.er.usgs.gov/ publication/wri914047.]

Ott, D.S., Edwards, D.D., and Bartholomay, R.C., 1992, Water-level data for selected wells on or near the Idaho National Engineering Laboratory, Idaho 1983 through 1990: U.S. Geological Survey Open-File Report 92-643 (DOE/ ID-22105), $307 \mathrm{p}$. 
Pittman, J.R., Fischer, P.R., and Jensen, R.G., 1988, Hydrologic conditions at the Idaho National Engineering Laboratory, 1982 to 1985: U.S. Geological Survey Water-Resources Investigations Report 89-4008 (DOE/ ID-22078), 73 p. [Also available at http://pubs.er.usgs.gov/ publication/wri894008.]

Plummer, L.N., Rupert, M.G., Busenberg, Eurybiades, and Schlosser, P., 2000, Age of irrigation water in ground water from the eastern Snake River Plain aquifer, South-central Idaho: Ground Water, v. 38, no. 2, p. 264-283.

Robertson, J.B., Schoen, Robert, and Barraclough, J.T., 1974, The influence of liquid waste disposal on the geochemistry of water at the National Reactor Testing Station, Idaho, 1952-1970: U.S. Geological Survey Open-File Report 73-238 (IDO-22053), 231 p.
Spinazola, J.M., 1994, Geohydrology and simulation of flow and water levels in the aquifer system in the Mud Lake area of the eastern Snake River Plain, eastern Idaho: U.S. Geological Survey Water-Resources Investigations Report 93-4227, 78 p.

Swanson, S.A., Rosentreter, J.J., Bartholomay, R.C., and Knobel, L.L., 2003, Geochemistry of the Birch Creek drainage basin, Idaho: U.S. Geological Survey WaterResources Investigations Report 03-4272 (DOE/ID-22188), 36 p. [Also available at http://pubs.er.usgs.gov/usgspubs/ wri/wri034272.]

U.S. Geological Survey, 1985, National water summary 1984-Hydrologic events, selected water-quality trends, and ground-water resources: U.S Geological Survey Water Supply Paper 2275, 467 p. 


\section{Appendix A. Geophysical Logs and Construction Information for Selected Wells at the Idaho National Laboratory, Idaho}

Appendix file is available for download at http://pubs.usgs.gov/sir/2015/5085. 
Publishing support provided by the U.S. Geological Survey Science Publishing Network, Tacoma Publishing Service Center

For more information concerning the research in this report, contact the Director, Idaho Water Science Center

U.S. Geological Survey

230 Collins Road

Boise, Idaho 83702

http://id.water.usgs.gov 
